\title{
Quicksilver Deposits
}

of the Horse Heaven

Mining District

Oregon

GEOLOGICAL SURVEY BULLETIN 969-E

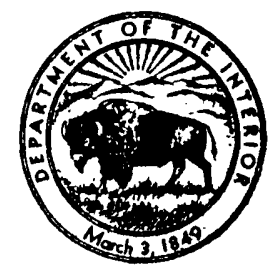





\title{
QUICKSILVER DEPOSITS OF THE HORSE HEAVEN MINING DISTRICT, OREGON
}

\author{
By A. C. Waters, Randall E. Brown, Robert R. Compton, Lloyd W. \\ Staples, George W. Walker, and Howel Williams
}

\section{ABSTRACT}

Commercial quantities of cinnabar were discovered in the Horse Heaven district, north-central Oregon, in 1933 . The district has since produced 15,000 flasks of quicksilver, most of which has come from the Horse Heaven mine, although the Axe Handle mine produced about 150 flasks. Four prospects contain some cinnabar that may be mined for quicksilver in the future.

The ore deposits found thus far are closely related to volcanic plugs. Four of them occur in or near autobrecciated plugs of biotite rhyolite. The ores of the Axe Handle mine are in altered rocks at the margin of a plug of augite andesite.

A small outlier of pre-Tertiary metamorphic rocks occurs about 5 miles north of the Horse Heaven mine. The oldest rocks close to the mine, however, are andesite flows, tuffs, and tuffaceous sedimentary rocks of the Clarno formation. The Clarno rocks were deformed, eroded to a rolling surface, and then covered by three series of volcanic rocks. The oldest consists of basaltic andesite; followed-after a period of erosion-by biotite rhyolite flows and pyroclastics. It is in the rhyolite plugs formed during this period of volcanism that most of the quicksilver deposits are found. Finally, the rhyolite flows and tuffs were moderately eroded, and in the southern part of the area they were covered by flows of augite andesite.

Most of the cinnabar at the Horse Heaven mine fills openings in autobrecciated parts of a southwestward-pitching rhyolite plug. Two dikes, one extending northwestward and the other southeastward from the plug, also are mineralized, as is the crest of a protrusion of the plug on its west side. A sheet of clay, which is an ancient soil developed at the unconformity between the tilted Clarno formation and younger pumiceous rhyolite tuffs, is in contact at many places with the upper or southwest side of the plug. Many of the steeply dipping ore shoots in the plug end upward against this clay, and just below it some especially rich ore was found.

Geologic evidence appears to warrant further prospecting and development. Even though the richest and most thoroughly mineralized section of the rhyolite plug has probably been exhausted, considerable undeveloped ore may still remain in the Horse Heaven mine. A few prospects that show cinnabar. in or adjacent to other volcanic plugs may also repay development; west and northwest of the area mapped there are many plugs of biotite rhyolite, but very little prospecting appears to have been done. In the Horse Heaven district, prospectors have often been misled by cinnabar float and large masses of mineralized rock 
that have been carried miles from their parent ledges by soil creep and landslides. It should be borne in mind that ore has been found in the district only in or near volcanic plugs.

\section{INTRODUCTION}

The Horse Heaven mining district lies in the eastern part of Jefferson County, a little north of the center of the State of Oregon. (See fig. 7.) It can be reached from Madras, a small town 45 miles to the west on U. S. Highway 97, or from Mitchell, about 40 miles to the southeast on U. S. Highway 28. A graded but otherwise unimproved road, difficult of passage in wet weather, connects Madras and Mitchell via the Horse Heaven mine.

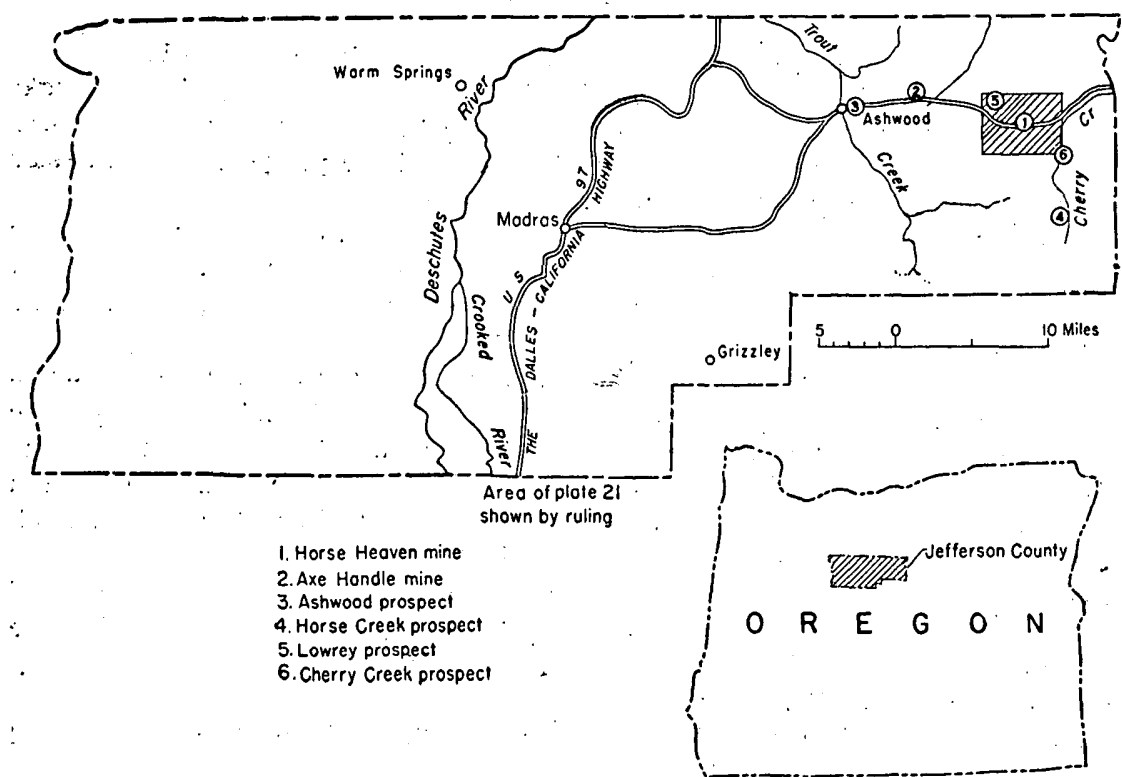

(Figdra 7.-Index map of Jefferson County, Oreg., showing location of quicksilver mines and prospects.

The region is rugged, with a maximum range in elevation of a little over 3,000 feet; the relief within the district is about 1,500 feet. The mountains in which the district lies belong to a group of dissected lava plateaus and isolated fault-block ranges that extend across northcentral Oregon and almost connect the Cascade Range with the Rocky Mountains. The west end of the group is near Redmond, Oreg., and its east end is in the Seven Devils region of Idaho. The eastern part of the group is called the Blue Mountains; the western part, which includes the Horse Heaven district, is generally called the Ochoco Mountains but in local usage is sometimes referred to by other names. A large part of the Ochoco Mountains is drained by the middle course of the John Day River, and this part is often referred to as the John Day. 
Basin. The Horse Heaven district lies at the western edge of the John Day Basin near the point where the John Day River turns abruptly north and enters a narrow canyon cut in the younger basaltic lavas of the Columbia River plateau. Some of the local inhabitants restrict the mame Ochoco Mountains to the elevated area south and southeast of the John Day Basin, thus excluding the Horse Heaven district.

The Horse Heaven district has a semiarid climate, with cold winters and hot summers. Barren hills dotted with scattered clumps of sagebrush and juniper characterize its landscape, but along permanent streams there is a heavy growth of trees and brush, and a few of the higher mountains receive enough rain to support forests of yellow pine. Rainfall is generally too scanty to permit agriculture without irrigation, but stock raising is an important industry.

Although some land was staked for gold and silver as early as 1865, no important mining was carried on in the region until 1934, when the Horse Heaven quicksilver mine (pl. 20A) came into production. The discovery of cinnabar, the principal ore of mercury, is credited to A. J. Champion, who found the mineral while panning on Cherry Creek and then traced the float to the clay and gravelly soil in a small saddle on the divide between Horse Heaven Creek and Cherry Creek. This saddle is in sec. 12, T. 10 S., R. 18 E., just north of Horse Heaven Mountain. Although Champion established the presence of cinnabar float throughout a considerable area near the saddle, he failed to find the mineral in place. His claims were subsequently bought by $\mathbf{R}$. $\mathbf{R}$. Whiting, whose son, Ray Whiting, Jr., with his friend Harry Hoy, traced the mineral to its source in ledges of altered platy rhyolite at the northern base of Horse Heaven Mountain. In 1933 Whiting drove the first, or Discovery, adit into this rhyolite and started development work lower on the hillside on what is now level 1 of the mine. He bought and installed a Herreshoff furnace, and production began in September 1934. In 1936 the property was acquired by Horse Heaven Mines, Inc.

Cinnabar was soon discovered at several other places in the district, but up to 1944 quicksilver had been produced only at the Horse Heaven and Axe Handle mines. The total production of the district to the end of 1944 is given in the following table:

Quicksilver production, Horse Heaven district, Oregon, in flasks of 76 pounds

\begin{tabular}{|c|c|c|c|c|c|}
\hline Year & $\begin{array}{l}\text { Horse } \\
\text { Heaven } \\
\text { mine? }\end{array}$ & $\underset{\text { Axe }}{\text { Aandle }}$ & Year & $\begin{array}{l}\text { Horse } \\
\text { Heaven } \\
\text { mine }{ }^{1}\end{array}$ & $\begin{array}{c}\text { Axe } \\
\text { Handle } \\
\text { mine? }\end{array}$ \\
\hline \multirow{2}{*}{$\begin{array}{l}1934 \\
1935 \\
1936 \\
1937 \\
1938 \\
1940\end{array}$} & \multirow{2}{*}{$\begin{array}{r}176 \\
781 \\
1,781 \\
2,107 \\
2,190 \\
1,668 \\
1,626\end{array}$} & \multirow{2}{*}{$\begin{array}{r}6 \\
23 \\
6 \\
4\end{array}$} & \multirow[t]{2}{*}{$\begin{array}{l}1941 \\
1942 \\
1943\end{array}$} & $\begin{array}{r}1,940 \\
1,243 \\
911 \\
674\end{array}$ & \begin{tabular}{r}
12 \\
50 \\
43 \\
\hdashline \\
\end{tabular} \\
\hline & & & & 15,097 & 144 \\
\hline
\end{tabular}




\section{FIELD. WORK AND ACKNOWLEDGMENTS}

Field work for this report was done by a Geological Survey party consisting of Randall E. Brown, Robert R. Compton, George W. Walker, A. C. Waters, and Howel Williams. It was begun on July 20, 1942, and completed on November 18, 1942. Maps of the underground workings were brought up to date in December 1943 and October 1944. During most of the field work not more than two members of the party were in the field at any one time. The report was written by A. C. Waters with the collaboration of Randall E. Brown and Robert R. Compton.

Lloyd W. Staples, geologist for Horse Heaven Mines, Inc., contributed freely the knowledge he had gained while directing development work at the Horse Heaven mine. Although the conclusions of the Geological Survey men differ in some respects from Staples' earlier geologic results, his preliminary work was of considerable assistance, and he is therefore included as a coauthor of the report. We are greatly indebted, also, to other officials of Horse Heaven Mines, Inc. : Frank Lewis; superintendent and resident engineer, provided much valuable information on the early development of the mine, its geology, and its mining problems; S. H. Williston, vice president, assisted in obtaining the aerial photographs used as a base map; and E. E. Gardanier, general manager, gave the party permission to live in his pleasant cottage.

At the Axe Handle mine L. C. Swanson and Guy Wharton were helpful in many ways.

\section{GEOLOGY}

\section{SUMMARY}

Most of eastern Oregon is covered with lava flows, chiefly basalts of Miocene to Pleistocene age. North of the Horse Heaven district these lavas belong mainly to the Miocene Columbia River basalt. This basalt appears to the south and west as well, but there the surface is formed for the most part by younger basaltic and andesitic rocks.

The Ochoco and Blue Mountains contain extensive areas of Eocene and pre-Tertiary rocks, which lie unconformably beneath the Miocene and post-Miocene rocks of the surrounding lava plateaus. These older rocks may in part represent the higher summits of a former east-west mountain range, which projected as islands, or steptoes, above the lava floods. Since extensive remnants of the Columbia River basalt and other younger lavas and sediments occur well within the confines of the province, however, the older rocks now exposed in the region may at one time have been completely or almost completely buried. Folding and some faulting occurred in the late Miocene, and after the deposition of Pliocene sedimentary and volcanic rocks the region 


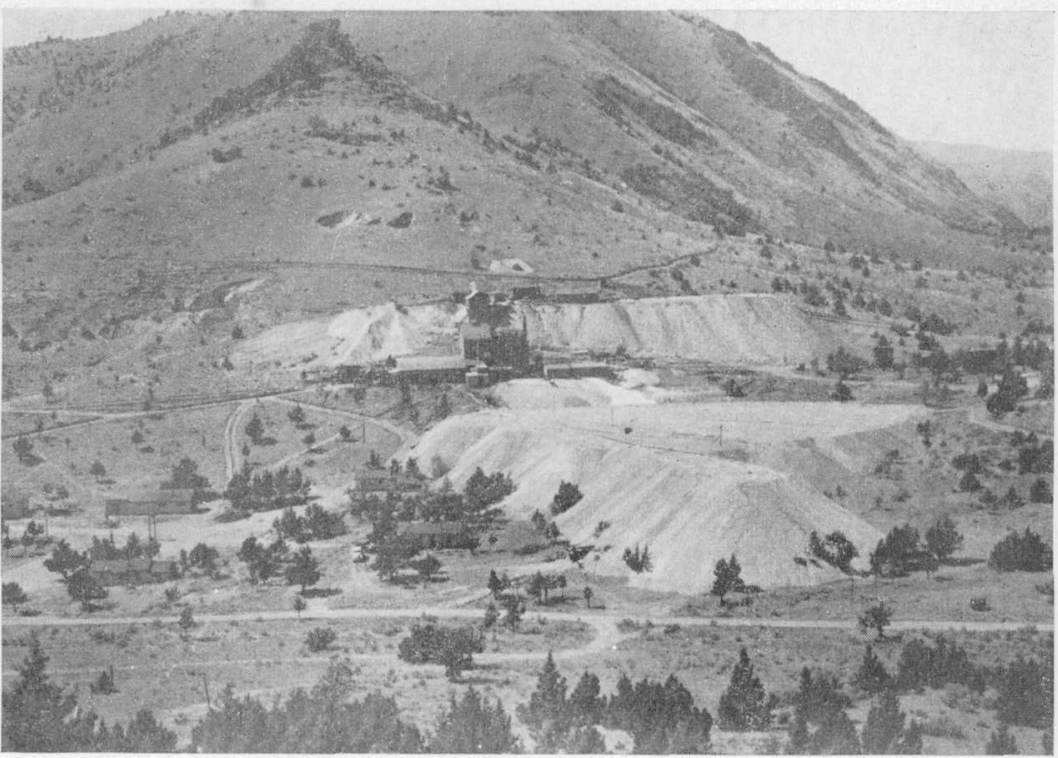

A. HORSE HEAVEN MINE, LOOKING SOUTH.

Horse Heaven Mountain, composed of pumice lapilli tuff, in background. Rhyolite intrusion and stratified tuffs of Clarno formation underlie smooth slope in middle distance in which glory holes appear.

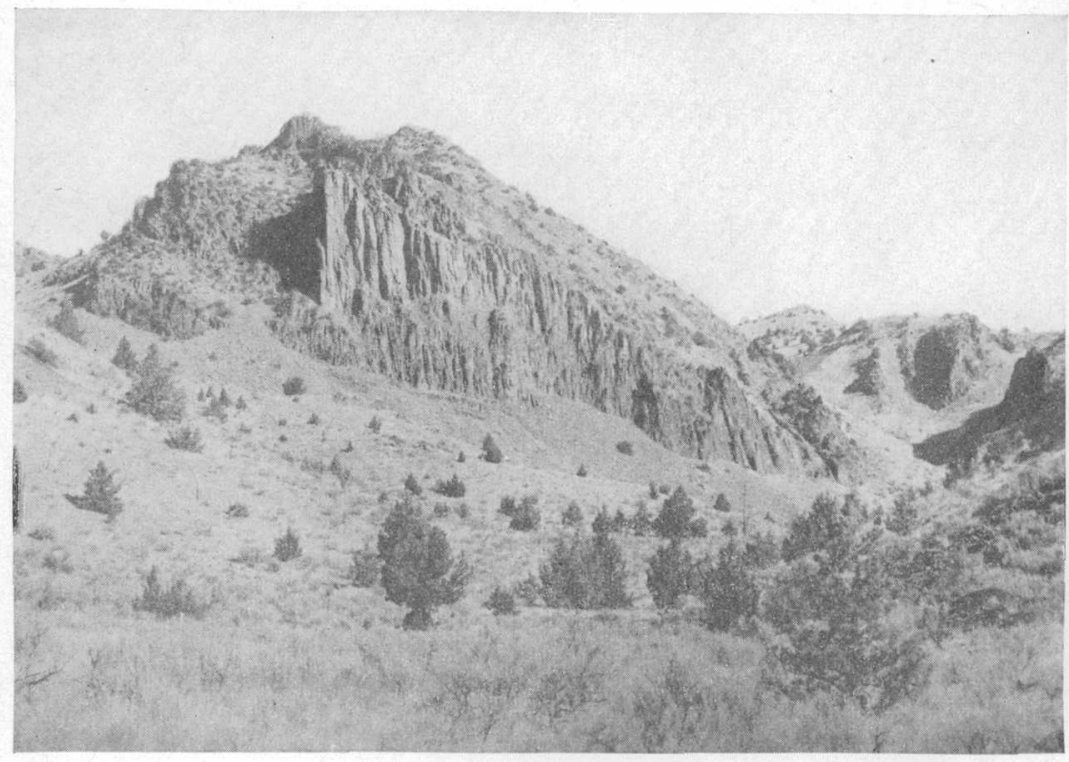

B. ANDESITE INTRUSION.

Tuffs and mudflows of Clarno formation form walls of hornblende andesite plug.

HORSE HEAVEN DISTRICT, OREG. 
was again broadly uparched and, in places, folded and faulted along east-west axes. Erosion then removed much of the late Tertiary volcanic cover and exposed the older rocks.

In the Horse Heaven district (pl. 21) the oldest rocks are andesites, tuffs, and tuffaceous sediments that constitute a part of the Eocene Clarno formation. Numerous volcanic necks and dikes, some of them of Clarno age, occur in the district. . Rocks of pre-Tertiary age are not common in the western part of the Ochoco Mountains, although they underlie large areas in the Blue Mountains and in the southeastern part of the Ochoco Mountains. A few miles north of the Horse Heaven district, however, slates and quartzites much older than the Clarno formation occupy about 3 square miles at the junction of Muddy and Currant Creeks. Fragments of the slates are occasionally found as inclusions in the tuffs and volcanic necks of the Clarno formation and of younger volcanic formations in the Horse Heaven district, indicating that the metamorphic rocks probably underlie the entire area at relatively shallow depths.

The Bridge Creek beds-often referred to as the upper Clarnoand the John Day formation are widely exposed east of the area shown on the geologic map (pl. 21).

In the area mapped, the Clarno formation has been regionally tilted to the north and northeast. Long-continued erosion then beveled the upturned andesites and tuffaceous sediments of the Clarno formation and reduced the area to a hilly, rolling landscape with a relief of only a few hundred feet. A thick coating of residual soil rich in clay developed on this surface. Next, flows of andesite, closely akin to basalt, poured over the erosion surface, but they either did not cover the entire surface or have been removed from parts of it by erosion. Several volcanoes then erupted and built large cones of pumiceous tuffs and nonporphyritic, platy rhyolite flows. After some erosion had taken place, floods of andesitic lava buried parts of the rhyolite cones and covered large areas on the older erosion surface to the south. The post-Clarno rocks have in general been very little deformed, but in places they are tilted a few degrees.

Solfataric alteration of the volcanic rocks in the area is common. The ferromagnesian minerals and the feldspars of the Clarno rocks in certain localities are completely replaced by secondary products. Some of the volcanic necks in the Clarno formation are strongly altered. The platy rhyolites and associated pyroclastic rocks of the younger volcanoes are for the most part fresh, but adjacent to volcanic necks they are commonly silicified, chloritized, and impregnated with marcasite, carbonates, silica minerals, and-locally-cinnabar. All the quicksilver mines and prospects in the district are in or near the margins of volcanic plugs: The youngest andesites are for the 
most part entirely fresh, but in a few localities they show mild hydrothermal alteration.

Since the last volcanic outbursts, erosion has produced a rugged topography in which the volcanic necks and the resistant rhyolite and andesite lavas stand in relief above the softer tuffs and sediments. In spite of this ruggedness, however, adjustment of the river and the more sizable creeks to structure is far from complete; most of the larger streams flow in courses that were probably cut down through the young volcanic cover with which the area once was mantled and are superimposed on the older rocks.

Landslides and modified soil glaciers are characteristic of the area. In particular, the clayey residual soil that lies at the unconformity between the Clarno formation and younger rocks. serves as a lubricant on which the overlying andesites, rhyolites, and pyroclastic rocks have moved under the influence of gravity.

\section{IITERATURE}

The geology and, especially, the paleontology of the John Day Basin have been treated in many publications, several of which describe and analyze the flora of the Clarno formation of Cherry Creek in the Horse Heaven district. ${ }^{1}$

The geology, apart from the paleobotany, of the Cherry Creek area is treated in some detail by Merriam, ${ }^{2}$ and the petrography of the Cherry Creek rocks has been described by Calkins. ${ }^{3}$ The geology of the quicksilver deposit at the Horse Heaven mine is described by Schuette ${ }^{4}$ and briefly summarized by Staples. ${ }^{5}$

The present writers, however, are at variance with Schuette in that they consider the rock in which most of the ore is deposited at the Horse Heaven mine to be an intrusive of platy biotite rhyolite, not a "hard silicified tuff." They likewise differ from Schuette, and from Staples in his earlier reconnaissance interpretations, on the following points: (1) Although some of the rocks in the mine belong to the Clarno formation, the biotite rhyolite in which most of the ore occurs is younger; it intrudes not only the Clarno formation but a

\footnotetext{
xnowiton, F. Xx., Foesli Gora of the Johm Day Rnain, Oreg.; T. S. Geol. Survey Bull. 204. 1.902 ; Merriam, J. C., Tertiary faunas of the John Day region: California Univ., Dept. Geol. Sci., Bull., vol, 5, pp. 171-205, 1907; Chaney, R. W., Fossil floras of the John Day

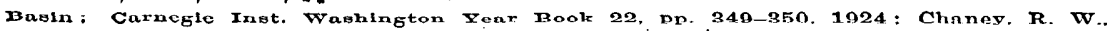
Suggestions regarding the age of the southern Cascade Range: Geol. Soc. American Bull., vol. 41, pp. 147-148, 1930 .

a Merriam, J. C., A contribution to the geology of the John Day Basin : California Univ., Dept. Geol. Sci., Bull., vol. 2, pp. 285-291, 1901.

${ }^{8}$ Calkins, F. C., A contribution to the petrography of the John Day Basin: California Univ., Dept. Geol. Sci., Bull., vol. 3, pp. 122-141, 1902.

${ }^{4}$ Schuette, C. N., Quicksilver in Oregon : Oregon Dept. Geology and Min. Industry Bull. 4, pp. 89-97, 1938.

'Staples, L. W., Geology of the Horse Heaven mine: Geol. Soc. American Bull., vol. 53, p. 1822,1942 .
} 
younger rhyolite flow and tuffs separated from the Clarno formation by an angular unconformity. (2) The black to dark-gray altered igneous rock in the mine is an andesite, not a basalt, and it is regarded by the writers as forming a series of lava flows interbedded with the tuffaceous beds of the Clarno formation, rather than as intrusive into the Clarno. (3) Proximity to a complex volcanic center of biotite rhyolite, rather than the presence of what Schuette calls "a strong fault [that] strikes northwest," is believed to be of most importance in the structural control of the ore deposit. The so-called "fault" is an angular unconformity along which there has been local shearing.

\section{STRATIGRAPHY AND PETROGRAPHY}

The general sequence of rocks in the Horse Heaven district and the distribution of the more important rock units in the vicinity of the Horse Heaven mine are shown on the geologic map (pl. 21), the' base for which was prepared from aerial photographs made by Brubaker Aerial Surveys: For purposes of mapping, the Clarno formation was split into four subunits that grade into one another along the strike and are therefore more nearly facies rather than true members. Plugs, pyroclastic rocks, and lavas of the younger biotite rhyolite volcanoes also have been mapped separately.

\section{PRE-TERTIARY ROCKS}

Within the area covered by plate 21 , pre-Tertiary rocks are represented only by occasional inclusions in tuffs and volcanic necks of the Clarno formation and in the pumice lapilli tuffs erupted as nuées ardentes from the younger rhyolitic volcanoes. Pre-Tertiary rocks are exposed in place, however, at the Muddy Ranch, 5 miles north of the area, where slates, schists derived from siltstones, and impure, poorly sorted carbonaceous quartzites alternate in highly folded and contorted beds. The prominent slaty cleavage of these rocks crosses the bedding at all angles; it is variable in attitude but usually dips southeastward. According to Merriam, ${ }^{6}$ the slates are of pre-Knoxville age.

\section{ClarNo formation}

The name Clarno formation was given by Merriam to a group of lava flows, volcanic breccias, tuffs, and tuffaceous sediments that he described as being typically exposed "at Clarno's Ferry on the John Day, east of Antelope, near the town of Fossil, on Cherry Creek, and near Burnt Ranch." " Within the area shown in plate 21, the Clarno

\footnotetext{
- Merriam, J. C., A contribution to the geology of the John Day Basin: Callfornia Univ., Dept. Geol. Sc1., Bull., vol. 2, p. 280, 1901.

7 Idem, p. 285.
} 
formation appears at the surface chiefly along a strip about 4 miles long and $11 / 2$ to 2 miles wide lying between Cherry Creek and Horse Heaven Mountain. In the central and western part of the area, it is buried beneath the andesite flows and the rhyolite volcanoes that make up the higher ridges, but in the southern part erosion has cut deeply enough to reveal large patches of Clarno rocks. Small outliers occur, also, along Horse Heaven Creek and Muddy Creek.

The succession of rocks that makes up the Clarno formation can best ibe observed in the hills just west of Cherry Creek, where it is almost continuously exposed. The formation is almost entirely of volcanic origin, although much of the pyroclastic material was sorted and laid down by water and some of it was weathered to clay soon after deposition. The prevailing strike of the beds is west, but in the northern part of the area it swings to west-northwest. The beds $\operatorname{dip} 10^{\circ}$ to $20^{\circ} \mathrm{N}$. or NE. They form a broad homocline, which was eroded to a rolling surface before the younger, nearly horizontal formations were deposited.

\section{SUBDIVISIONS}

The part of the Clarno formation that is represented in the district has been subdivided, for mapping, into four main units; in places minor subdivisions of these four units also are indicated on plate 21 . The uptilted beds between the southeastern corner and the northern edge of the area are 5,800 feet thick, but it should be emphasized that neither the top nor the bottom of the formation is exposed and that nearly all the measured units vary greatly in thickness along the strike. The four main units are briefly described below :

Unit 1.-The oldest beds in the area are andesite flows interbedded with layers of clay. The flows crop out boldly in ledges; the thin layers of clay between the flows are mostly covered. The andesites are medium gray to black on fresh surfaces but weather to a characteristic chocolate brown. They usually show well-developed platy jointing; more rarely, the jointing is columnar. The flows are lenticular, commonly 15 to 30 feet thick.

The layers of clay between the andesite flows are varicolored in shades of maroon, chocolate brown, and buff. Many of them appear to have been derived from bedded tuffaceous materials, but some were probably formed by deep weathering of the underlying andesite flows in a wet subtropical climate. These are ancient residual soils, preserved by burial under later flows of andesite.

The ithickness of the andesite flows and clays exposed along Cherry Creek within the area mapped is 600 feet. The flows are cut by a few andesite dikes and two volcanic necks.

Unit 2.-The andesites and interbedded clays of unit 1 are overlain by a mappable unit, 1,350 feet thick on Cherry Creek, consisting of 
tuffs, bedded tuffaceous clays, volcanic mudflow deposits, and a few thin andesite flows. The lower beds, though locally they include: coarse mudflows, are mostly fine-grained and well bedded. They/ are: rich in fossil plants. Higher in the section fine-grained silty layers are interbedded with sandy lenses, and still higher the beds become: increasingly, coarse until bouldery volcanic mudflows predominate. Interbedded with the coarse mudflows, however, is a distinctive and persistent layer of tuffaceous clay about 150 feet thick.

The colors of these rocks vary from. white in the fine-grained tuffs to light buff, lavender, green, and brown in the coarse tuffaceous sands and mudflow deposits. The tuffaceous clays are varicolored in pastel shades of red, green, and brown. Dependable measurements of strike and dip are easily obtained in the lower silty, fossiliferous layers, and the mudflows are locally separated by sand lenses in which the dip can be measured approximately. The attitude of the beds conforms with that of the andesite flows to the south.

Much of the material of this unit is pyroclastic debris of andesitic composition sorted and laid down by streams. Some thin-bedded clays and some silty layers containing upright stems of Equisetum were probably laid down in marshes or shallow ponds and lakes. Much of the coarser material was deposited as volcanic mudflows, and some of the fine-grained tuffs accumulated directly from showers of ash and lapilli that were not reworked by water.

Unit 3.-About 1,750 feet of tuffaceous clay, with occasional beds of coarse tuff and a few andesite flows, overlies unit 2 conformably. These rocks may be subdivided from the base upward as follows: (a). 600 feet of tuffaceous clay, including at least one andesite flow and a few 3- to 5-foot beds of white tuff; (b) 50 feet of pure-white pumice lapilli tuff, forming a very distinctive bed; (c) 100 feet of andesite flows; (d) 1,000 feet of tuffaceous clay with some thin layers of papery and sandy tuff. This unit contains no andesite flows.

The tuffaceous clays, which especially characterize this unit of the Clarno formation, are beautifully colored in smoky white and pastel shades of lavender, maroon, chocolate brown, buff, green, and gray green. They crop out in low, rounded, completely barren hills. The clay was formed chiefly by weathering of fine andesitic ash, probably in a moist subtropical climate. The weathered ash accumulated partly on river flood plains but mainly, perhaps, in marshes and in shallow lakes and ponds. When wet, the clay forms a slimy, tenacious mud which contracts greatly as it dries and develops a popcornlike surface on which no bedding is visible. Dips can usually be observed, however, in nearby interstratified layers of papery and sandy, tuffs.

Unit 4.-The clays of unit 2 grade upward into white, coarsegrained tuff's and sandy tuffs that are largely rhyolitic in composi- 
tion, although andesitic material is still abundant. These tuffs, with occasional layers of tuffaceous clay and at least one group of andesite flows that thickens greatly in the western part of the area, form the uppermost mappable unit in the Clarno formation within the :area covered by plate 21 . The unit is at least 2,100 feet thick; its top is not exposed. The sequence within the unit near the eastern edge of the area is as follows: (a) 850 feet of interbedded clays and tuffs, including about 150 feet of andesite flows near their upper limit. (The rock described by Calkins ${ }^{8}$ as a quartz basalt belongs here.) (b) 1,250 feet of coarse sandy tuffs and lapilli tuffs, which form the most northerly exposures in the series. This group of tuffs is mostly light-colored and in part rhyolitic. The unit is cut by numerous masses of intrusive andesite.

\section{PETROGRAPHY OF ÁND̃ẼSTTES}

From the foregoing section it can be seen that andesitic lavas occur in the Clarno formation at several horizons and that andesitic debris is the principal component of most of the tuffs, tuffaceous sediments, and mudflows.

The andesites of the Clarno formation have been described petrographically by Calkins.9. They are chiefly augite andesites, but they also include hypersthene-augite andesites, hornblende andesites, olivine andesites, and a few rocks containing both olivine and quartz. All the lavas examined. show a characteristic alteration. The formation of iddingsite and zeolites is common in these rocks, as is noted by Calkins. In addition, other secondary products-especially chlorite, carbonates, and wispy patches of serpentine minerals-occur in the andesite flows, and clay minerals are abundant in some of them. Decomposition of ferromagnesian phenocrysts to opaque masses containing abundant hematite is very common. The feldspar microlites, where fresh enough for determination, are andesine, generally near labradorite in composition. The plagioclase phenocrysts are mainly andesine, but they show oscillatory and progressive zoning and may have cores of sodic labradorite. The monoclinic pyroxene is commonly augite; in some rocks it is pigeonite. Most of the hypersthene is completely decomposed. The textures are pilotaxitic and hyalopilitic. Foreign inclusions of quartz surrounded by reaction rims of augite are sometimes present.

The andesite at the Horse Heaven mine forms a series of flows interbedded with the tuffs and tuffaceous sediments of the Clarno formation. Most of it is so altered that its original composition is obscure, but the andesitic textures are preserved even in rocks com-

${ }^{8}$ Calkins, F. C., op. cit., p. 134.

${ }^{9}$ Calkins, F. C., op. cit. 
pletely converted to clay. At coordinates $8205 \mathrm{~N}$. and $4785 \mathrm{E}$. on level 6, some of this lava is fairly fresh. Although the feldspar contained in it is a calcic andesine, the rock is closely akin to the basalts, as shown by its high percentage of ferromagnesian minerals. These include both augite and highly altered hypersthene and, in some specimens, large spots of greenish serpentinous products probably derived from former olivine phenocrysts. Olivine has been definitely identified in one of the flows interstratified with sediments of the Clarno formation near Cherry Creek, and Calkins reports it in the lava that he calls a quartz basalt.

Although most of the lava flows of the Clarno formation are typical andesites, many of them are difficult to classify. A considerable number are near the border line between basalt and andesite. If the composition of the feldspars is used as a basis of classification, all but a few are andesites. On the other hand, the high ferromagnesian content of some lavas is more typical of basalts, and a few of the olivine-bearing specimens contain zoned plagioclase phenocrysts with cores of labradorite. Rocks of this kind are widespread in the Cascade.Range and have been variously classified by different observers.

\section{INTRUSIVE BODIES PROBABLY OF CLARNO AGE}

In the Horse Heaven district, especially its northern part, the Clarno formation is cut by many volcanic plugs and a few dikes. The plugs are rudely circular to oval in outline and vary considerably in size. Many are about 600 feet across, five in the northern part of the area are at least 1,500 feet long, and one in the northeastern corner ( $\mathrm{pl}$. $20 B$ ) is more than a mile in diameter. Dikes are comparatively rare; a few occur as offshoots of plugs, but others are not connected with plugs at all.

The age of the volcanic plugs is open to question. Although most are believed to be of Clarno age, some may be much younger. The majority consist of andesite in which the chief ferromagnesian mineral is basaltic hornblende, and since no flows of hornblende andesite were seen in the Horse Heaven district, it might easily be assumed that these plugs are later than the Clarno. It is quite possible, however, that plugs and domes of hornblende andesite may have formed at the same time the abundant pyroxene andesite flows were erupted. East of the area, moreover, there are volcanic mudflows in the upper part of the Clarno formation that contain abundant blocks of andesite with phenocrysts of basaltic hornblende, which, like the basaltic hornblende of many of the plugs, has been altered in places to bright flakes of hematite. North of the Horse Heaven district, also, flows of hornblende andesite were found within the Clarno formation at levels stratigraphically above the rocks of the Clarno formation exposed in 
the Horse Heaven district. For these reasons it is believed that most of the plugs are of Clarno age but that the flows from these volcanic centers may be largely confined to parts of the Clarno formation younger than those exposed in the Horse Heaven district.

Some of the plugs consist of augite andesite and augite-hypersthene andesite similar to the lavas in the lower part of the Clarno formation. Some of the intrusive pyroxene andesite plugs contain xenocrysts of quartz. The neck just east of Muddy Creek, near the northern edge of the area covered by plate 21 , consists in part of a cream-colored felsite in which quartz is an original constituent.

The plugs vary greatly in structure. Some of them-for example, the one in the east-central part of sec. 5, T. 10 S., R. 19 E.-consist entirely of vent breccias composed of a chaotic assemblage of andesite fragments. Others are massive and coarsely jointed; because of their resistance to exrosion they stand above the rest of the country as castle- like spires surrounded by talus. Still others are closely jointed, and the rock comprising them has undergone so much hydrothermal alteration that it is soft and does not crop out prominently. A few of the plugs, excellent examples of which occur on Cherry Creek just east of the area mapped, have beautifully developed columnar jointing. The columns in the outer part of the neck are horizontal at right angles to the nearest cooling surface. They generally extend inward 10 to 30 feet from the contact and are then interrupted by an essentially vertical parting. Similar vertical partings, roughly cylindrical and spaced at irregular intervals, may parallel the first. With increasing distance from the edge of the plug, the columns gradually curve upward, and near the center of the plug they are generally vertical.

Brecciation is often found even in the columnar and massive plugs, particularly toward the edges. Vertical zones of strong alteration marking the channels of rising gases and solutions also are common. In one plug, a central core 300 feet across has been completely altered to clay and carbonates by rising gases and hydrothermal solutions.

By far the largest intrusive mass in the district is the one in the northeast corner (pl. 20B). This mass forms a dome-shaped mountain with an area of nearly 1 square mile. The rock is very distinctive; it was originally a hornblende andesite, but the large, needlelike phenocrysts of basaltic hornblende are in most places completely altered to a mixture of bright-red hematite and other decomposition products. Hematite is also scattered through the groundmass of much of the rock, giving large areas of the plug a salmon-pink color. In the outer part of the mass there are widely spaced semicolumnar to blocky joints, so oriented as to give the upper part a domelike appearance. A small outcrop of the same kind of andesite just to the west contains phenocrysts of unaltered basaltic hornblende; this may be a satellitc of the larger intrusion. 
Practically all the lavas and tuffs of the Clarno formation have been altered by hot gases and liquids. The amount of alteration varies greatly; some rocks show only mild attack of the more susceptible ferromagnesian minerals, whereas others are completely replaced. As previously noted, many volcanic necks in the Clarno are extensively altered by solfataric action; in parts of them the andesite is completely broken down to clay. The alteration of these andesites has been desoribed by Calkins, ${ }^{10}$ who emphasizes particularly the development of iddingsite from hypersthene and of zeolites from plagioclase. Other changes commonly seen in these rocks are chloritization of augite, development of bastite and other serpentine minerals from orthorhombic pyroxene, devitrification of the glassy groundmass of the andesites to mosaics of feebly birefringent substances, and-rarely-complete conversion of the groundmass and the feldspar phenocrysts to mixtures of zeolites, carbonates, and clay. The common transformation of basaltic hornblende to aggregates of bright-red hematite and opaque black material in some of the volcanic plugs and mudflow breccias in the northern part of the area has already been mentioned. Other ferromagnesian minerals show the same alteration locally. In some rocks hematite is dusted through cracks in the feldspars and in the groundmass in sufficient quantity to give the rock a pink or salmon color on fresh fracture.

Alteration similar to that described has been observed in the western Cascades in rocks of roughly the same age as the Clarno. ${ }^{11}$

\section{AGE AND CORRELATION}

Fossil plants collected from the Clarno formation on Cherry Creek have been studied by many paleobotanists, all of whom believed the flora to be of Eocene age and to indicate a humid subtropical climate. Chaney ${ }^{12}$ has correlated the formation, on paleobotanical evidence, with beds along the western slope of the Oregon Cascades. Hodge, ${ }^{13}$ using only lithologic evidence-a poor basis for correlation of volcanic sequences-suggests that the Clarno rocks of the Horse Heaven district extend westward beneath the younger lava flows and reappear at the surface in the canyon of the Deschutes River and on the western

${ }^{10}$ Calkins, F. C., op. cit., pp. 124-125, 130.

${ }^{11}$ Callaghan, Eugene, and Buddington, A. F., Metalliferous mineral deposits of the Cascade Range in Oregon: U. S. Geol. Survey Bull. 893, pp. 10-15, 1938; Wells, F. G., Preliminary geologic map of the Medford quadrangle, Oregon Dept. Geology and Min. Industry, 1939; Williams, Howel, The geology of Crater Lake National Park, Oreg.: Carnegie Inst. Washington .Pub. 540, p. 14, 1942.

${ }^{13}$ Chaney, R. W., Ancient forests of Oregon; A. study of earth history in western America : Carnegie Inst. Washington Pub. 501, pp. 631-648, 1938.

${ }^{13}$ Hodge, E. T., Geological map of north-central Oregon : Oregon Univ. Pub., Geology ser., vol. 1, no. 5, 1932. 
slopes of the Cascade. Range. The Calapooya formation, ${ }^{14}$ which crops out in the western foothills of the Cascades almost due west of the Ochoco Mountains, contains a flora similar to that of the Clarno formation. It also resembles the Clarno formation in its lithologic peculiarities and its widespread hydrothermal alteration. A concise summary of the probable relations of the Clarno formation to the rocks of the western Cascades has been given by Williams. ${ }^{15}$

\section{POST-CLARNO ROCKS}

\section{ANCIENT SOIL AT UNCONFORMITY ABOVE CLARNO FORMATION}

An angular unconformity separates the northward-tilted Clarno rocks from a younger series of flows and pyroclastic rocks, which are horizontal in most places though locally tilted at a slight angle. The unconformity is a rolling surface with an original relief of a few hundred feet. In most places the Clarno rocks immediately below the unconformity are thoroughly weathered; the depth of the weathering ranges from a few inches to at least 100 feet but is usually about 10 to 20 feet. The weathered material is everywhere a clay, often indistinguishable lithologically from the bedded tuffaceous clays and intraandesite clays of the Clarno formation. Its position, however-at the surface of unconformity as a sheet lying across the edges of the upturned Clarno rocks-differentiates it from the clays interbedded with the Clarno formation. It was mapped wherever possible and was found to cover a large part of the ridge crests that slope from Horse Heaven Mountain toward Cherry Creek and to occupy a considerable area along the lower part of Horse Heaven Creek. Much of the course of Muddy Creek in the area covered by plate 21 coincides closely with the surface of unconformity. Just upstream from the Gonser . Road, Muddy Creek is still cutting down in basaltic andesites that appear to have filled an old valley on the surface of unconformity, ibut both upstream and downstream from this locality the heavy clays at the surface of unconformity largely mask the underlying Clarno rocks. : On the northeast side of Hinkle Butte, clay at the unconformity rests on andesite of the Clarno formation and is immediately overlain by a flow of rhyolite erupted from the Hinkle Butte volcanic center.

The varicolored clays at the surface of unconformity contain much petrified wood and occasional streaks of lignite. On the Gonser Road, about half a mile northeast of the Muddy Creek crossing, twigs and poorly preserved fossil leaves are found in the clay just below a flow of basaltic andesite. Elsewhere the clay contains, or grades into, gravel beds and sand lenses marking the courses of old streams on the

\footnotetext{
${ }^{14}$ Wells, F. G., and Waters, A. C., Quicksilver deposits of southwestern Oregon : U. S. 'Geol. Survey Bull. .850, 1934.

15 Williams, .Howel, op. eit., pp. 11-15.
} 
surface of unconformity. A fairly persistent gravel bed of this kind occurs along Muddy Creek just beneath the rhyolite of Hinkle Butte in sec. 36, T. 9 S., R. 18 E. The cliff forming the waterfall on Horse Heaven Creek in the western part of sec. 1, T. 10 S., R. 18 E., exposes an andesite flow that followed a stream bed on the surface of unconformity and incorporated stream pebbles and fine debris in its base. At both these localities the pebbles are mainly of andesite and other materials derived from the Clarno formation, but some of them are of quartzite and slate, which indicates that erosion had completely removed the Clarno formation from some areas before the eruption of the younger, horizontal volcanic rocks.

Mapping of the clay at the unconformity presented great difficulties because of the sliding of the overlying flows and tuffs on this lubricating surface. False outcrops of the overlying rocks are often found hundreds of feet and sometimes several miles out of position as a result of gliding on the clay surface under the influence of gravity.

This clay is important in the ground-water geology of the region. It forms an impermeable barrier, above which lie many perched water tables. At least three-fourths of the springs within the area mapped come to the surface where the top of the clay has been revealed by erosion.

\section{BASALTIC ANDESITE}

The first eruptions that followed the development of the erosion surface above the Clarno formation covered the clay at the unconformity with porphyritic dark-gray to black lavas. The phenocrysts in these lavas are mostly of serpentinized ferromagnesian minerals, and where abundant they give the rock a greenish cast. In contrast to the andesites of the Clarno formation and to the younger augite andesites, these rocks rarely contain phenocrysts of plagioclase. Scoriaceous zones are commonly found at the tops of the flows, whereas in the andesites of the Clarno individual flows are more often separated by clay. It is difficult, however, to distinguish these flows in the field from either the older or the younger andesites unless their stratigraphic relations are clearly apparent. They show the same typical platy jointing and weather to the same characteristic chocolate brown as the other andesites.

If this group of lavas once covered the entire Horse Heaven district, instead of merely filling depressions on the eroded Clarno surface, it was later removed from most of the area by erosion, so that only disconnected patches were left at the time the overlying rhyolites and rhyolite tuffs were erupted. Several remnants of these lavas occur as filling in old valleys on the Clarno erosion surface.

No complete petrographic study of these flows was made, but in the thin sections observed the lavas are considerably richer in ferro- 
magnesian minerals than the post-rhyolite augite andesites, and are similar in general to the more basic varieties of andesite in the Clarno formation. Hypersthene and augite are constant constituents. Much of the augite is fresh, but the hypersthene is usually represented by pseudomorphs of serpentinous material. Pseudomorphs of olivine phenocrysts appear in a few specimens. The plagioclase, which rarely forms phenocrysts, is usually andesine, but in a few specimens it is sodic labradorite. The rocks of this series are difficult to classify, but most of them-like the basic varieties of andesite in the Clarno-are closely akin to basalt and in this report are called "basaltic andesite."

Volcanic plugs definitely related to the basaltic andesite are not so conspicuous in the field as those described in connection with the Clarno formation. Two small masses of brecciated andesite that occur in the remnant of basaltic andesite on Horse Heaven Creek are believed to be of intrusive origin. In the more easterly of the two the contacts are obscure, but in the other the breccia appears definitely to cut across the adjacent lavas. Many flows in this area, however, have brecciated tops, and it is possible that the supposedly intrusive breccia is merely a remnant of the upper surface of a flow. Three similar masses of brecciated basaltic andesite in the southwestern corner of the area also are believed to be plugs.

\section{RHYOLITE AND ASSOCIATED PYROCLASTICS}

Volcanic centers.-After the erosion of the basaltic andesite, flows of biotite rhyolite and sheets of coarse pumice lapilli tuff were erupted from closely spaced centers in the Horse Heaven district. Around two of these centers (Burnt Butte and West Rock), large tuff cones were built and rhyolite flows poured out in minor volume. From each of two others (Hinkle Butte and Muddy Butte), a viscous protrusion emerged and swelled at the surface into a thick domical flow of rhyolite (pl. 21). Some tuff was erupted from the Muddy Butte center before the flow, but no large tuff cone was built. An elongate plug of biotite rhyolite, closely associated with a small circular mass of vent breccia, occurs on Horse Heaven Creek, a short distance from its junction with Muddy Creek. The rhyolite flows and lapilli tuffs of the adjacent area may have been derived from this center.

Of the volcanoes that erupted both flows and tuffs, that of Burnt Butte is the best exposed and most interesting. Deep dissection has revealed a central plug of biotite rhyolite with highly contorted, locally autobrecciated, steeply dipping flow structures. This plug is flanked by the remains of a low flat cone, or dome-shaped mass, composed of unbedded pumice lapilli tuff. The original slope of the cone was probably about $10^{\circ}$ to $15^{\circ}$. Flows of biotite rhyolite that spilled over the tuff are extensively exposed on the north side, where they 
extend across the Gonser Road and into the valley of Horse Heaven Creek. Possibly the larger of the two rhyolite masses on the southwest side of the Burnt Butte volcano may also be the remnant of a flow; its margins are completely mantled by slides and talus that make precise observation of its contacts impossible, but judging from the attitude of its flow structures and its relation to the pumice lapilli tuff, it is probably a domical protrusion of pelean type. It is alined with two spinelike protrusions punched through the tuff.

Other subsidiary protrusions have been driven through the cone at several places. Three more protrusions, together with a dikelike body with slickensided walls, cut the pumice lapilli tuff on the east wall of the canyon of Muddy Creek just upstream from the Gonser Road. At least two project into the rhyolite flows on the north side of the cone, and there may be still others in this area, for the intrusive rhyolite is not easily distinguished from that of the flows.

The West Rock volcano is particularly interesting because of its close association with the ores of the Horse Heaven mine. It is very similar to the Burnt Butte volcano. The cone, however, has been largely obliterated by erosion; the most extensive remnant is the great pile of pumice lapilli tuff and tuff-breccia that forms most of Horse Heaven Mountain. On its north and west sides denudation has completely separated the West Rock plug from the tuffs and lavas that were erupted from it, exposing the basaltic andesite upon which the cone was built. The subsidiary intrusions associated with this plug are fewer than those associated with the Burnt Butte volcano, unless :some of them lie buried under the tuffs from Burnt Butte and the thick regolith of this area. The most important one is a plug of irregular but rudely circular outline about 250 feet in diameter, in which most of the ore found in the Horse Heaven mine was deposited. Two dikes extend from this plug, one to the northwest and the other to the southeast. Two additional poorly expased rhyolite masses, one just northwest of West Rock and the other about 3,000 feet to the east-southeast, are also interpreted as intrusive. All three intrusions, as well as the dikes that extend from the mass in the Horse Heaven mine, lie near a northwest-southeast line passing through the West Rock plug.

Areas of hydrothermal alteration in the pumice lapilli tuff of Horse Heaven Mountain may mark the site of similar intrusions not yet revealed by erosion.

Many hills of Clarno rocks and of basaltic andesite along the Gonser Road between the Horse Heaven mine and Cherry Creek are capped with platy rhyolite. Some of this rhyolite probably came from the West Rock plug or its associated protrusions, although part of it must have had its source in the eruptive center of Hinkle Butte. The rhyolite flow in the west part of the Horse Heaven mine may have 
come from either souree. The eruption of the flows was followed by explosive activity, which built up the great sheet of pumice lapilli tuff of which Horse Heaven Mountain is a remnant.

Nuée ardente deposits.-The rhyolitic pumice lapilli tuff, which is such a prominent constituent of the Burnt Butte and West Rock volcanoes and which oceurs locally elsewhere in the Horse Heaven district, is remarkable in many ways. Near the base of the deposit finegrained, moderately well bedded tuffs occur at some localities. The top of the deposit, in the few places where it has been preserved from erosion, also shows thin layers composed of varying proportions of ash, pumice, and erystals, which probably fell directly from the air in volcanic showers. By far the greater part of the deposit, however, is a sheet of totally unbedded and unsorted material, composed of a matrix of glass shards and small bits of pumice enclosing larger pumice lapilli and lithic fragments. The pumice lapilli and lithic: fragments vary in diameter from 0.005 inch to 1 or 2 feet. In much of the deposit they are about the size of a hazelnut. There seems to. be little correlation between size of fragments and distance from vents, nor are systematic size variations in the vertical direction very apparent, although the coarsest material appears to lie about twothirds of the way up from the base of the deposit. At most places: stratification is entirely absent, but here and there thin lenses of finegrained tuff appear between much thicker beds of unstratified coarsematerial. These are more common in the pumice lapilli tuffs from: Burnt Butte than in those on Horse Heaven Mountain. Near Burnt. Butte the lenses dip away from the Burnt Butte plug on all sides at. angles of $5^{\circ}$ to $15^{\circ}$; on Horse Heaven Mountain they dip to the: southwest at low angles.

The features described are characteristic of deposits formed by: glowing avalanches or nuées ardentes like the one that issued from: Mont Pelee on the island of Martinique to overwhelm St. Pierre.. Perhaps the first eruptions were mild explosions, after which thegrains now forming the stratified tuff fell gently from volcanicshowers, but the bulk of the deposit was violently spread out by glowing avalanches or "sand flows" that boiled from the craters and spilled" over their edges in the form of a chaotic jumble of pumice fragments: mixed with chips of rock torn from the walls of the conduit. The. comparatively rare thin lenses of fine-grained tuff were probably formed by the settling of dust and ash during brief intermissions between the outbursts of glowing avalanches. Toward the end of the period of activity the avalanches finally ceased, and minor explosions gave rise to showers of fine ash, which settled over the unstratified deposits to form the upper bedded tuffs. 
The petrography of the pumice lapilli tuff and tuff-breccia bears out the nuée ardente theory of origin. The matrix of the rock is composed of tiny shards of rhyolite glass containing elongated bubbles. Embedded in this matrix are a few crystals of quartz and sanidine and rare euhedral crystals of biotite. Pumice fragments of the same nature as the glass shards are abundant; they range in size from microscopic bits to large blocks. Most of them are nonporphyritic; but a few bits of pumice with phenocrysts of quartz and sanidine can be found in most specimens. Other common fragments are bits of flowbanded stony rhyolite similar to that found in the flows and plugs. Inclusions of foreign material are abundant. They consist mainly of chips of andesite and basaltic andesite derived from the base on which the cones rest. Bits of tuffaceous sandstone and of other rocks from the Clarno formation can usually be found, and at most. localities diligent search will bring to light a few chips of the slate and quartzite that underlie the Clarno rocks. Chips of platy andesite, however, are everywhere the most abundant of the foreign inclusions; in parts of the deposit they make up as much as 10 percent of the: rock, though in most specimens they constitute less than 2 percent. Because of their black color they stand out conspicuously in the white matrix of the tuff and seem more abundant than they really are. In thin sections it can be seen that most of the andesite chips were so greatly reheated in the glowing avalanche that their ferromagnesian minerals were completely altered to aggregates of fine-grained opaque material. The feldspar was similarly altered; in some fragments it has been partially fused, but in most it has only been made somewhat. clearer and fresher looking by the reheating.

Flows and plugs.-With the one exception noted below, the rhyoliteflows are surprisingly uniform. Most of them are nonporphyritic, although some contain a few small scattered phenocrysts. They are exceptionally platy and can often be split into sheets nearly as thin. as slates. The layering is commonly horizontal near the base of a. flow, but in the middle and upper parts it is highly contorted and: usually dips at steep angles.

In thin sections these rhyolites are seen to have a flow-banded' groundmass crowded with tiny crystallites. Phenocrysts are rare or absent; when present, they comprise embayed quartz, sanidine, zoned calcic oligoclase, and biotite. Spherulites and lithophysae are rare. Much of the rhyolite is slightly devitrified and contains mosaics of birefringent substances with sutured boundaries. Wisps and long ribbonlike areas of secondary quartz follow the flow banding. Many cracks parallel to the banding or, more rarely, across it are lined with tridymite. 
One flow, which grades downward into a flow breccia containing angular fragments of stony rhyolite, is mapped separately on plate 21. Unlike the other rhyolite flows it is highly porphyritic, containing abundant large phenocrysts of quartz; glassy-clear, zoned oligoclase; sanidine; and a few smaller phenocrysts of biotite. The groundmass is like that of the other rhyolite flows but more thoroughly devitrified. As this flow is capped in one place by a tiny remnant of andesite and in some localities is overlain by the nonporphyritic rhyolite of Hinkle Butte, it may be considerably older than the other rhyolite flows.

The rhyolite of the plugs and domes is very similar to that of the flows, and in some places, especially where plugs swelled directly into flows at the surface, no distinction can be made between the intrusive and the extrusive rock. The rock of the plugs, however, generally differs from that of the flows in several respects. In most plugs the platy banding is much more contorted than it is in flows. Where it is orderly enough to map, it commonly dips toward the center of the plug at steep angles. Much of the rhyolite in the plugs is broken into masses of breccia, the origin of which is not altogether clear. In part these breccias must be the result of autobrecciation, for in some places plastic rhyolite has welled into and even partially incorporated fragments of brecciated rhyolite, and transitions can be found between the two. In some cases the brecciation was probably due to near-surface explosions within the plugs, but in most cases it was probably caused by differential flow in the almost solid rising mass. In the West Rock plug and in the ore-bearing intrusion exposed in the workings of the Horse Heaven mine there are numerous faults bordered with breccia, but the faults pass gradually, within a few feet, into zones of highly contorted flow banding. Parts of the plug appear to have been solid enough to break and shear while other parts were flowing viscously under the stresses induced by the rise of the plug. The zones of autobreccia have served as channels for rising gases and liquids, which altered the adjacent rhyolite and in a few places completely converted it to clay. Many of the ore shoots at the Horse Heaven mine were deposited in these zones of breccia.

In nearly all the rhyolite plugs the rocks are at least slightly altered by hydrothermal solutions, and devitrification has proceeded farther in them than in the flows. In some plugs nuch of the rock has been so profoundly altered by rising gases and liquids as to be thoroughly hleached and completely devitrified. In some of the thoroughly altered rock there are only local remnants of the original volcanic textures.

- Although perlite and other forms of volcanic glass are found in flows at a few localities, perlite occurs much more commonly along the margins of plugs. Fairly extensive masses of perlite may be seen 
on the south edge of the West Rock plug, on the south and east edges of the elongate plug crossing Horse Heaven Creek near its junction with Muddy Creek, and along both margins of the small rhyolite protrusion just east of the point where the Gonser Road crosses Muddy Creek.

It may justifiably be asked whether the area shown on plate 21 as an indefinitely bounded plug on Hinkle Butte is in reality the source of the Hinkle Butte rhyolite or whether this rhyolite issued from the West Rock center. The rhyolite of this particular part of Hinkle Butte has many features that are characteristic, in general, of the rhyolite known to occur in plugs. For example, it shows highly contorted flow banding that for the most part dips steeply toward the center of the mass, and in places the rock is autobrecciated. Small areas of hydrothermal alteration, including one small mass of altered. perlite, occur in it. Nevertheless, no clear-cut margins were found between this central rhyolite mass, which has the characteristics of a plug, and the surrounding rhyolite, which has the characteristics of a flow. Therefore it is believed that Hinkle Butte marks the site where a viscous protrusion of rhyolite reached the surface and swelled into a thick flow. (See cross section $B-B^{\prime}$ of pl. 21.)

\section{AUGITE ANDESITE}

In the southern part of the Horse Heaven district the products of the rhyolitic volcanoes are buried under nearly horizontal flows of feldspathic augite andesite. Along the centact between the augite andesite and the rhyolite tuff-breccia southeast and east of Burnt: Butte, it can be seen that the rhyolitic volcanoes underwent some erosion before the andesite was erupted. The remnants of the rhyolitic cones, however, must have been larger at the time of the eruption of the augite andesite than they are now, for they appear to have acted' as a dam that kept the augite andesite from reaching the central and. northern parts of the Horse Heaven district.

The augite andesite differs in many respects from the older basaltic: andesites and the andesites of the Clarno formation. Except in the immediate vicinity of volcanic plugs, the augite andesite is entirely unaltered. It is more feldspathic than the older andesites, and in the one thin section examined the only ferromagnesian mineral is augite. The phenocrysts are plagioclase that has oscillatory zoning, although its range in composition is within that of andesine. Magnetite and: apatite occur as accessories, and some vesicles are lined with a greenish clay that may be nontronite.

Individual augite andesite flows are as much as 75 feet thick. These lavas are black or dark gray on fresh fractures, but many of the flows have tops of reddish scoria. 
One of the feeders through which this andesite rose to the surface is well exposed at the southeast end of Horse Heaven Mountain (pl. 21). It is a plug of roughly oval plan with a maximum diameter of about 700 feet. It intrudes both the rhyolite tuff of Horse Heaven Mountain and the augite andesite flows. Around this plug there.is a wide aureole of hydrothermal alteration ( $\mathrm{pl} .22$ ), in which the andesites are bleached and softened and locally impregnated with sulfur crusts and much carbonate. At least one sulfur spring is associated with the plug.

A poorly exposed dike or elongate volcanic neck of augite andesite cuts rhyolite and tuff just east of the Burnt Butte rhyolite plug. At its eastern end there is a considerable area of hydrothermal alteration, in which the pumice lapilli tuff is locally colored bright green by disseminated chlorite.

\section{AGE OF POST-CLARNO ROCKS}

No reliable evidence has been obtained regarding the age of the clays at the unconformity and of the post-Clarno rocks above it. Nowhere in the area mapped are younger fossiliferous rocks exposed by which they might be dated. The lithology of the post-Clarno rocks gives no help in correlating them: similar volcanic rocks occur in the Rattlesnake formation of Pliocene age; in the John Day formation, which is considered to be of middle and upper Oligocene and lower Miocene age; in the Clarno formation, and in other formations of widely differing age. The inconclusive evidence available at present suggests that the basaltic andesites and the rhyolite flows and tuffs are of early Tertiary age and may be approximately contemporaneous with the John Day formation. It is also possible that some of the volcanic rocks here described as post-Clarno may be of Clarno age, but that seems improbable in view of the great extent of the unconformity and the great length of time necessary for its formation. The augite andesites, as previously explained, are younger than the rhyolite flows and tuffs and may be of late Tertiary age.

The dating of the unconformity and the determination of the age of the post-Clarno rocks are of considerable importance, not only in solving the stratigraphic problems of central Oregon, but also in determining the age of the mineralization. As stated elsewhere in this report, the mineralization is believed to be related to the post-Clarno intrusions; the mineralizing solutions, released from the crystallizing magmas beneath the area, are believed to have risen within and adjacent to the volcanic plugs and formed the cinnabar deposits. If that is true, dating the post-Clarno volcanic rocks would also date the mineralization.

SURFICIAL DEPOSITS

The abundance of landslides and rock glaciers in the Horse Heaven area has already been mentioned. Although slides are particularly 
large and numerous where heavy lava flows and massive tuffs overlie the slippery clays at the unconformity above the Clarno formation, they are by no means confined to such localities. Slides develop on nearly every steep slope, irrespective of the nature of the underlying rock. Many resistant volcanic plugs are completely surrounded by slides and talus.

The streams of the area are still cutting down, but resistant masses of volcanic rock form temporary base levels on both Muddy and Cherry Creeks. Upstream from these masses very narrow, discontinuous flood plains floored with a few feet of poorly sorted gravels and sands have developed:

\section{ORE DEPOSITS}

\section{STRUCTURAL CONTROT}

The quicksilver ores of the Horse Heaven district are closely related to volcanic plugs. Every locality where cinnabar or other mercurybearing minerals were seen in place lies in or near a pipelike mass of intrusive rock. At the Horse Heaven mine, the Ashwood prospect, the Horse Creek prospect, and the Lowrey prospect, the associated plug is composed of biotite rhyolite. At the Axe Handle mine, the ores are found just outside the margin of a plug of glassy feldspathic augite andesite similar to the younger augite andesites of the Horse Heaven district.

Although volcanic plugs thus constitute the major control in the localization of the ore deposits, individual ore shoots owe their position and richness to a complex combination of minor structural features. As the cinnabar was carried in ascending hydrothermal solutions that probably had their source in the last residues of a crystallizing magma beneath the area, the hydrothermally altered parts of the plugs and adjacent wall rocks are more favorable for the occurrence of ore shoots than the unaltered rocks. In general, also, cinnabar was deposited in minable quantities only in the more permeable rocks'; autobrecciated portions of the plugs and dikes, as well as zones of breccia along faults that cut the plugs or the adjacent wall rocks, are therefore especially favorable sites for ore shoots.

Particularly rich ore is commonly found in breccias just beneath cappings of clay or other impermeable rock. At the Horse Heaven mine the capping clays are of diverse origins: some were formed by hydrothermal alteration of rhyolite, tuff, or andesite; others are gouges along faults; and still others are bedded deposits of tuffaceous clay or fine-grained tuff. The most important capping clay, however, is the soil formed on the surface of unconformity cut across the Clarno formation.

Contacts of intrusive rhyolite with andesite are locally favorable for the development of ore shoots, especially where the andesite over- 
lies the rhyolite. Where that is the case, the andesite is generally altered to a relatively impermeable, mealy rock largely composed of clays and carbonates, and cinnabar is likely to have been precipitated in the autobrecciated margin of the rhyolite just beneath the andesite. Similar relations hold where the rhyolite has been intruded into tuffaceous clays or other impermeable rocks. Some small ore shoots are found in the wall rock a few feet above the intrusive mass, but they are almost invariably confined to faults and other permeable zones. One ore shoot at the Axe Handle mine reverses the common relation: the Axe Handle plug enlarges greatly near the surface, and ore is: found at one place in brecciated and altered wall rock capped by the outward-flaring margin of the plug.

\section{MINERAIOGY}

The ores of the Horse Heaven district contain a varied and interesting assemblage of minerals, including some rare species that have: not yet been identified with certainty. The mineralogy of the district: is only briefly outlined here.

As in practically all quicksilver mines, the most abundant ore mineral is cinnabar $(\mathrm{HgS})$. Native mercury $(\mathbf{H g})$ is locally abundant. Metacinnabar, the black sulfide of mercury, is scarce but rather widely: distributed. A dark-gray to black, antimony-bearing cinnabar oc-curs in the Red Jacket claims at the Axe Handle mine, and minute crystals of it have been found in the Horse Heaven mine. Spectroscopic analysis shows appreciable amounts of gold and silver in this cinnabar, as well as antimony. There are several other mercurybearing minerals, but they occur in such minute quantities as to be of little economic importance.

The principal gangue minerals are marcasite, carbonates, and the silica minerals. Gypsum occurs in many places, most abundantly in some of the ore from the Axe Handle mine. Stibnite, also, is a. fairly common constituent of ores from the Axe Handle mine. Jarosite is locally abundant, and several other fine-grained substances; occur but are unidentified. Pyrite is relatively scarce; realgar, orpiment, and stibiconite are very scarce.

Minerals formed by alteration of the wall rocks are abundant and varied. Chlorite, carbonates, iddingsite, zeolites, and minerals of the serpentine and limonite groups are found, but the clay minerals are the most important. The clay is largely montmorillonite, but other clay minerals, which have not been precisely identified, are common.

No detailed studies of paragenesis have yet been made, but observations with a hand lens show that there was much overlapping and probably more than one cycle of ore deposition. The first effect of 
the hydrothermal solutions appears to have been the alteration of the waill rocks to clay minerals, but this process locally overlapped the deposition of silica and cinnabar and in places even continued after mineralization had ceased. Silicification followed, and again there is evidence of more than one stage of introduction of silica minerals. Marcasite is, in general, later than silica. In places the marcasite - occurs in veinlets, but most of it is disseminated through the clays and . altered rhyolites as intricate frills and chains of minute euhedral -crystals. Cinnabar appeared at about the same time as marcasite, but its deposition continued longer. Some of the metacinnabar occurs in linings of vugs in the middle of cinnabar veinlets and thus appears to be definitely later than the cinnabar, but some of it is cut by veinlets - of cinnabar and is studded with small crystals of cinnabar growing from its surface. The main period of carbonate deposition appears to have followed the precipitation of cinnabar, but at least some of the carbonate was deposited simultaneously with cinnabar and in places veinlets of cinnabar cut veinlets of carbonate. Jarosite is a late mineral, and in most localities gypsum is still later, but at one ;place in the Axe Handle mine gypsum is cut by veinlets of cinnabar. "The rare mercury minerals are latest of all. Some of them were undoubtedly produced by oxidation and other weathering changes long after deposition of the hypogene minerals. Melanterite is being deposited today at many places in the Axe Handle mine where seepages of water occur.

\section{SUGGESTIONS FOR PROSPECTORS}

All deposits of quicksilver ore thus far found in the Horse Heaven district lie within or adjacent to intrusive masses. Plugs of biotite rhyolite appear to be the most favored intrusions, but the deposit in the Axe Handle mine is on the margin of a plug of augite andesite.

The best localities to prospect, therefore, are in and adjacent to the volcanic plugs, particularly those composed of biotite rhyolite. Ore deposits are likely to be found only in association with plugs that have undergone considerable hydrothermal alteration. However, because hydrothermal alteration softens the rock and makes it less resistant to erosion, unaltered plugs generally form prominent topographic features in the district and are easy to locate, whereas the highly altered plugs, which are more likely to contain ore, are much less conspicuous.

Plate 22 shows all plugs located and mapped in the Horse Heaven district, together with all observed areas of hydrothermal alteration. Doubtless some small areas of hydrothermally altered rocks have escaped observation because of the prevalence of slides and creeping soil. 
Numerous plugs of biotite rhyolite have been noticed in the unmapped area between Ashwood and the Axe Handle mine and in the drainage basin of Currant Creek west of Muddy Ranch. These areas appear to be particularly favorable for prospecting. Plugs of andesite are numerous to the north and east of the Horse Heaven district, especially near the mouth of Cherry Creek, near Burnt Ranch, and near Muddy Ranch. The wide aureole of hydrothermal alteration surrounding the augite andesite plug at the southeast end of Horse Heaven Mountain (pl. 22) likewise invites prospecting.

Areas of autobreceiation in the plugs-as: well as permeable zones formed by faults in or adjacent to the plugs-should be searched for, since they have proved especially favorable for ore deposition. It should be remembered, also, that at the Horse Heaven mine the clay at the unconformity above the Clarno formation is important as an impermeable cap to some of the ore shoots. This unconformity is widespread, and many of the plugs in the area cut through it. Moreover, beds of stratified clay and fine-grained tuff that might serve as a cap are common constituents of the Clarno formation.

In attempting to trace cinnabar to its source by panning, prospectors have been hampered and confused by slides and thick masses of creeping soil. There are numerous false outcrops-masses of mineralized rock containing cinnabar that have moved great distances from their parent ledges under the influence of gravity. Many shafts, pits, and adits have been driven into the creeping mantle, often at considerable expense, only to end in the barren rock below.

\section{MINES AND PROSPECTS}

\section{HORSE HEAVEN MINE}

The Horse Heaven mine, which is the only large producer in the district, is located in sec. 12, T. 10 S., R. 18 E., and sec. 7, T. 10 S., R. 19 E. It is owned by Horse Heaven Mines, Inc., whose main offices are at San Francisco, Calif.

The mine is on a north-facing slope at the base of Horse Heaven Mountain, just above the saddle that separates Horse Heaven Creek from Cherry Creek. In September 1945 the mine had been opened by means of 10 levels and several sublevels, which exposed the ore-bearing zone in a block about 1,300 feet long and 400 feet wide (pls. 23-35). The southeastern half of this block, however, has been penetrated only by level 1 and by three short sublevels. The vertical range of the workings is not great. The levels are only 20 to 56 feet apart, and level 10, with a floor elevation of 2,962 feet, lies only 383 feet below the highest level, or Lost Mine adit. Approximate floor elevations of the different levels are given in the following table: 


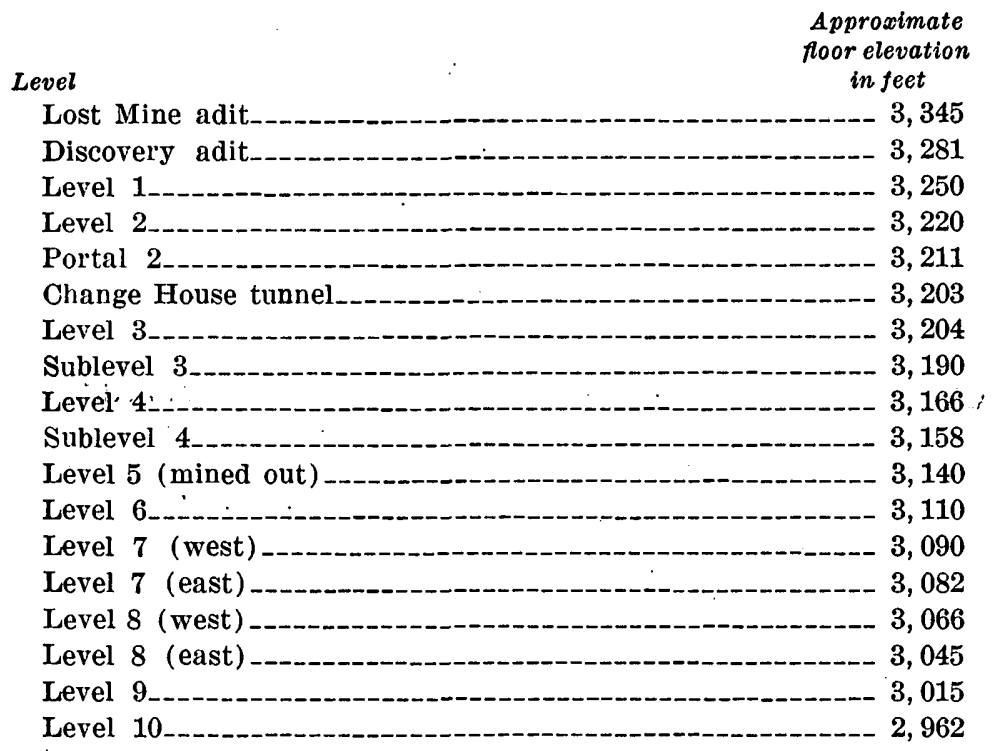

The main adit enters the hill at an elevation of 3,250 feet and leads to level 1. From this level two inclines extend downward, one to level 3 and the other to level 6. From'level 6 two steep'winzes lead to level 9. Ore from level 9 was raised by bucket to level 6 , hand-trammed to the incline in ore cars, then hoisted to level 1 and hand-trammed to the mill. To avoid this retramming and to develop the mine to still deeper levels, the Manway shaft was sunk in 1942 from the surface to level 10. The levels are connected by numerous raises and open stopes.

The reduction plant for the ore was just below the portal of level 1 . The Herreshoff furnace originally had four hearths, but it was afterwards enlarged to six hearths and had a capacity of 60 tons per day. Less than 40 tons per day, however, was being treated late in 1944 when the furnace was completely destroyed by fire. Power for the plant and mine prior to the fire was generated by two 125-horsepower Caterpillar Diesel engines attached to a generator and compressor, with a third engine set up to act as an auxiliary when either of the others was shut down. There was a well-equipped shop and assay office. Most of the assays were made by a special instrument devised by the company and based on the principle of the absorption of ultraviolet light by mercury vapor. The company has done considerable experimental work in improving quicksilver metallurgy, including the construction of condensers of a new type and the development of an especially sensitive apparatus, which makes use of the absorption of ultraviolet light, for checking furnace and stack losses. The mine and plant were carefully planned and well operated. 
GEOLOGY AND ORE DEPOSITS

In minor structural details the geology of the Horse Heaven mine is exceedingly complex, but the general pattern of the rock formations and their relation to the ore shoots can be readily grasped.

\section{RELATION OF ORE DEPOSITS TO RHYOLITE PLUG}

Extending through the mine is a highly autobrecciated rhyolite plug that is probably an offshoot from the nearby West Rock volcanic center. The wall rocks of the plug are andesite, clays, bedded tuffs, and unbedded pumice lapilli tuffs with a little rhyolite lava. This plug, which is rudely circular in plan, has a diameter of about 250 feet in the upper part of the mine, but below level 6 it widens in all directions. The plug was probably in a highly viscous condition when emplaced. As it rose, it greatly brecciated and domed the rocks along its margins, so that its edges are irregular and intricate in detail (pls. 27,32 , and 34). The contacts show obvious evidence of mechanical movement; where seen underground they have the appearance of faults, and for a few feet on either side of the wall both the rhyolite and the wall rock are locally converted to breccia. The plug is not vertical but pitches southwest. Between level 1 and level 6 the angle of pitch is roughly $50^{\circ}$ and its direction about $\mathrm{S}$. $75^{\circ} \mathrm{W}$., but as the .contacts are írregular and the vertical distance between the levels mentioned is only 140 feet, these figures may not be representative of the -plug as a whole.

Most of the larger and more productive ore shoots of the mine occur -within this plug. Almost all the rhyolite between level 1 and level 7 is altered and mineralized, but the productive ore shoots are largely confined to zones of autobrecciation and to bodies of breccia along steeply dipping minor faults. Such faults are numerous both within the plug and at its margins, but few of them extend far. Some of the ore shoots in the autobrecciated zones are pipelike bodies with indefinite walls; many of these are vertical, but some are inclined with the pitch of the plug. Other ore shoots, most of them tabular or oval in plan, follow the dip of minor faults. These faults, which are short and have little displacement, trend in all directions, although many of them roughly parallel the plug margins.

The steeply dipping ore shoots may be capped with clay; beneath these cappings the ore is often especially rich. Some cappings, mostly blackened with disseminated marcasite, have been formed by hydrothermal alteration of the intrusive rhyolite along flat or gently dipping shear planes. Many of the ore shoots, however, end against the bedded clays and pumice lapilli tuffs that make up the wall rock .on the southwest side of the plug. This is the direction in which the -plug pitches, and the steeply dipping to vertical ore shoots, if they 
extend upward far enough, eventually reach this overlying wall of the plug (pls. 30, 34).

The tuffs in the southwest wall have been dragged up and locally bowed outward by the plug. As a result, the dip of the bedding and the pitch of the plug are in the same direction, although the bedding usually dips at a considerably lower angle. The edge of the plug will coincide with the bedding for a short distance, then abruptly steepen so that it cuts across the bedding. These conditions alternate several times, giving the southwest edge of the plug the steplike profile shown in plates 30,32 , and 34 .

Along some of the flatter parts of this contact, lignite-bearing claythat at the unconformity above the Clarno formation, directly beneath the rhyolitic pumice lapilli tuff-lies above the intrusive contact and caps some of the stopes. In many places the clay has been slickensided and contorted by mechanical movement connected with the rise of the plug. Slickensides and other minor features commonly associated with faults are found, also, along the more steeply dipping parts of the intrusive contact where it cuts across the bedding, and it was these features that caused this contact to be called the "Horse Heaven fault" in earlier reports. ${ }^{16}$ Farther southwest, outside the plug, the continuation of this supposed fault has been reported at the end of the crosscut extending almost due south from a point near the head of the Little Flower stope on level 1 (pl. 24). What is visible here, however, is not an intrusive contact but an exposure of the somewhat sheared, lignitebearing clay at the unconformity.

Between level 6 and level 10 the plug has a protrusion on its west side, so that its plan below level 6 is like that of a pear lying on its side with the stem pointing west. The crest of the protrusion, though brecciated and irregular, plunges about $33^{\circ} \mathrm{W}$. The richest stopes thus far developed in the lower level are located along this crest and in the wall rocks just above. The protrusion appears to have been localized by the southwestward-tilted unconformity between the pumice lapilli tuff and the underlying mass of andesite. Its axis is in line with the unconformity, and the intrusive rhyolite of which it consists is capped on the northwest by andesite and on the southwest by rhyolite tuff, a rhyolite flow, and the lignite-bearing clay at the unconformity. Damming of the rising solutions by the clay produced a particularly rich ore shoot above level 9 in the intrusive rhyolite directly beneath the clay (pls. 29, 30 ). Mercury-bearing solutions also made their way into permeable zones in the brecciated andesite on the north side of the protrusion and developed smaller ore shoots in the andesite.

${ }^{16}$ Schuette, C. N., Quicksilver in Oregon: Oregon Dept. Geology and Min. Industry Bull. 4, p. 91, 1938; Staples, L. W., Geology of the Horse Heaven Mine : Geol. Soc. America Eull., vol. 53, p. 1822, 1942. 
Two prominent rhyolite dikes extend from the plug, one to the southeast and the other to the northwest. Both dikes are locally autobrecciated and are highly altered by hydrothermal solutions in some places. The southeastern dike has been exposed for a distance of about 600 feet in the workings on level 1 and, for much shorter distances, on levels 2 and 4 and in the Little Flower stope. At one place on level 1 where both walls are well exposed, the dike is 35 feet thick; at another place on the same level it is 55 feet thick; and in the extreme southeast end of level 1, where again both walls are well exposed, it is 80 feet thick. At the last-mentioned place a small ore shoot has been discovered and developed by three short sublevels 40,60, and 110 feet below level 1. A square-set stope also has been opened in the dike along its southeast contact with the rhyolite tuff (pls. 24,35).

The accessible workings do not afford sufficient information to determine the complete geologic control of the ore in the Little Flower stope. Most of the ore is in the dike, which below level 1 is separated from the main plug by the flow of andesite mapped on level 1 . This andesite flow dips $30^{\circ} \mathrm{N}$. and probably extends continuously as far as surface diamond-drill hole C-10, about 350 feet north of level 1 . On levels 4 and 6 the lower part of the andesite is intruded by the eastward extension of the plug, and on levels 1 and 2 the upper part of the andesite is overlain by the westward extensions of the dike. The Little Flower stope is in the lower part of the dike and in the upper part of the andesite flow, which here serves as the footwall of the ore body.

The northwestern dike, which is well exposed in levels $3,4,6,7$, and 8 , is similar in general character to the southeastern dike but thinner and shorter. It ends within 250 feet of the edge of the plug, and in the deeper levels of the mine it is only 15 to 20 feet thick. It dips to the southwest; the dip steepens and flattens locally but averages about $60^{\circ}$. Between levels 7 and 8 the dike and the andesite on the hangingwall side are heavily impregnated with marcasite, and in places they contain much cinnabar. Where the dike leaves the plug it is directly in line with the dike on the opposite or southeast side of the plug. The Sunshine stope extends along the northwestern dike, and the ore in the stope was largely obtained from the brecciated rhyolite of the dike, but part of it came from the tuff on the southwest or hanging-wall side. This part of the stope has been mined to the surface, but there is an underground extension of the stope that lies entirely in rhyolite tuff just above a rhyolite flow (pl. 33).

WALL ROCKS OF RHYOLITE PLUG

The walls of the intrusive masses of rhyolite consist of rocks belong-. ing to four main groups. These are, in ascending order, (1) tuffs and tuffaceous sediments of the Clarno formation; (2) altered andesite 
flows of the Clarno formation; (3) the clay, containing streaks of lignite, that lies at the unconformity between the Clarno formation and the overlying rocks; and (4) biotite rhyolite tuff, probably erupted from the West Rock volcanic center. Associated with this last-mentioned tuff is a thin flow of biotite rhyolite, well exposed at the west ends of levels 4 and 6 . The rhyolite flow is difficult to distinguish from the intrusive rhyolite where the stratigraphic relations are not apparent.

At a few places in the underground workings there are small isolated patches of tuff that have been largely altered to clay and do not show enough diagnostic characteristics to enable one to determine definitely whether they belong to the young rhyolite pumice lapilli tuff or to the older tuffs of the Clarno formation. These and other undifferentiated rocks are represented collectively by a special symbol (g) on the level maps and in the cross sections (pls. 24-35).

The north and northeast walls of the rhyolite intrusions consist mainly of tuffs and tuffaceous clays belonging to the Clarno formation. These rocks are well exposed in the adit of level 1 , where they strike N. $60^{\circ}-85^{\circ} \mathrm{W}$. and $\operatorname{dip} 40^{\circ}$ to $50^{\circ} \mathrm{NE}$. They are well bedded, and most of the beds are fine-grained. Similar tuffs in a highly altered and silicified condition are found along the edge of the rhyolite plug in the two crosscuts at the west end of level 1. In the southwest crosscut on this level they are overlain unconformably by coarse rhyolitic pumice lapilli tuff that dips to the southwest. One to two feet of waxy clay occurs along the contact.

Tuffs and tuffaceous clays believed to be a part of the Clarno formation are also found in the southeastern part of level 1 on the north side of the rhyolite dike. In this locality, especially near the head of the Little Flower stope, there are small patches of tuff, isolated by minor faults or by irregular intrusive contacts and too much altered to admit of their being definitely correlated with either the Clarno formation or the younger rhyolite tuff; however, a vertical hole (C-10) drilled from the surface north of this area, after having passed through 70 feet of landslide material, penetrated 180 feet of alternating fine-grained tuffs, carbonaceous clayey tuffs, bedded tuffaceous clays, and other rocks typical of the Clarno formation. The bottom of the hole is in andesite, evidently the downward continuation of the flow exposed southwest of the Little Flower stope. An underground drill hole (UG-40) extending northeastward from a point near the head of the Little Flower stope, two (UG-39 and UG-55) starting farther east on level 1, and one (UG-107) near the southeast end of level 1 also reveal fine-grained clays and tuffs typical of the Clarno formation in the ground immediately north and northeast of the rhyolite dike. 
The tuffs along the northeast side of level 3, which form the east wall of the Sunshine stope, probably belong to the Clarno formation. The spotty gray tuff that is most extensively exposed resembles one variety of the younger pumice lapilli tuff, but the same kind of tuff occurs in outcrops of the Clarno formation in the Cherry Creek area and a small thickness of it, intercalated between other sediments typical of the Clarno formation, was cut by drill hole C-10. Since the tuff has about the same strike and dip as tuffs of the Clarno formation in the adit of level 1 just above this area, it seems fairly safe to assign it to the Clarno. On the other hand, the tuff that occurs only 30 to 60 feet to the southwest, on the opposite side of the rhyolite mass in the Sunshine stope, dips southwest instead of northeast as the Clarno rocks do and is believed to be a part of the younger rhyolite tuff that makes up Horse Heaven Mountain.

Tuff and tuffaceous sediments, including some thin beds of pebbly tuff typical of the Clarno formation, occur at the east end of sublevel 4 , where they are in contact with altered andesite on the south and are cut off by the intrusive contact of the rhyolite plug on the west. Near the rhyolite contact they are greatly altered, have been partly converted to clay, and are colored dark gray to black by abundant small euhedral crystals of marcasite. Immediately adjacent to this area, at the east end of level 4, similar tuffs-also thoroughly impregnated with marcasite-occur in a highly brecciated condition at the edge of the rhyolite plug. The rhyolite at this point too is in part altered to a clayey mass containing much disseminated marcasite.

The andesite interbedded with the tuffaceous sediments of the Clarno formation in the Horse Heaven mine is mainly in two areas, one southeast of the plug and the other northwest of it.

The andesite southeast of the plug is best exposed on level 1, but its downward extension has been penetrated by the Little Flower stope, by level 4 (east), and by the crosscut that extends south from sublevel 4 just east of the $5100 \mathrm{E}$. coordinate. That this andesite continues farther to the north is revealed by vertical drill hole $\mathrm{C}-10$, which entered the andesite at an elevation of 3,020 feet after passing through 180 feet of typical Clarno sediments. If the andesite has the same strike as the tuffs of the Clarno, the change in elevation of the top of the andesite between level 1 and drill hole $\mathrm{C}-10$ indicates a dip of about $30^{\circ} \mathrm{NNE}$., which is consistent with the general dip of the Clarno rocks in this vicinity. At the end of the crosscut that extends south near the $5250 \mathrm{E}$. coordinate on level 1, the andesite is unconformably overlain by pumiceous rhyolite tuff. The typical clayey soil that nearly always marks this unconformity in the Horse Heaven district is well exposed and contains a thin bed of lignite. The clay has been somewhat disturbed by movement along the bedding. The andesite below it is thoroughly weathered. A rhyolite flow, up to 70 feet 
thick, lies unconformably above the andesite at the west ends of levels 7,8 , and 9 and is in turn overlain by the pumice lapilli tuff. This rhyolite flow pinches out downward between levels 9 and 10. The flow, judging from its orientation and position, probably came from the West Rock or the Hinkle Butte volcanic center.

The andesite on the northwest side of the rhyolite plug is exposed only in the deeper levels of the mine. It has been penetrated over a wide area on level 6 , and it is exposed continuously from level 6 to below level 9. The only place in the mine where the base of this andesite is exposed is in the Manway shaft, 16 feet above the level 10 station: This shaft passed through the andesite into pebbly tuffs and mudflows at an elevation of 2,988 feet. As the bottom of vertical drill hole C-9, about 270 feet north-northeast of the Manway shaft, is in andesite at an elevation of 2,958 feet, the andesite of the northwestern area-like that southeast of the plug-apparently dips to the north.

The andesite exposed in the deeper levels of the western part of the mine is the direct continuation of the dipping flows exposed southeast of the plug between level 1 and sublevel 4. The exposures are continuous except for an interval measuring 50 feet horizontally and 50 feet vertically between sublevel 4 and level 6 (east) in which no workings have been driven. If the andesite has the same nearly west strike and north dip as the adjacent Clarno sedimentary rocks, it would appear at successively deeper levels as the northeastern end of the mine is approached. The position of all the andesite penetrated by the workings of the mine can thus be explained by assuming that a sheet of andesite flows not over 200 feet thick is interbedded conformably with the Clarno formation.

In earlier published accounts of the mine,${ }^{17}$ it was stated that the andesite (called basalt) was intrusive into the biotite rhyolite plug (called tuff) and the adjacent wall rocks. That the rhyolite intrudes the andesite, however, is shown by the results of more recent investigation substantiated by the following evidence: (1) The rhyolite in many places is full of inclusions of the andesite-for example, near the andesite contact on level 6 and level 7 and in drill core UG-22. (2) A clearly exposed rhyolite dike extends through the andesite on levels 6,7 , and 8 . On level 7 and in drill hole $\mathrm{C}-6$ the entire thickness of the dike is penetrated, and andesite is revealed on both walls. The andesite is overlain unconformably by the pumice lapilli tuff and the ancient clay-rich soil, but these rocks have been intruded by the rhyolite plug and dikes. (4) The andesite is obviously altered, brecciated, and mineralized at its contacts with the rhyolite.

The general relation of the pumice lapilli tuff and of the clay at the unconformity along its base to the other rocks in the mine is well

\footnotetext{
${ }^{27}$ Schuette, C. N., Quicksilver in Oregon : Oregon Dept. Geology and Min. Industry Bull. 4, pp. 91-93, 1938.
} 
established. The tuff extends the entire distance along the southwest side of the mine workings. Where its bedding is visible, the tuff strikes northwest and dips $17^{\circ}$ to $45^{\circ} \mathrm{SW}$.; its average dip is about $30^{\circ} \mathrm{SW}$, and it is therefore strongly discordant with the andesite and other units of the Clarno formation. The strike and dip of the tuff and of the clay at the unconformity are fairly uniform where they rest directly on the Clarno sedimentary rocks and andesites, but in the central part of the mine, where they are intruded by the rhyolite plug, their stratification planes are bowed outward and are repeatedly broken and displaced upward along many small faults. Dips in this area are commonly steep.

At some places near its base the pumice lapilli tuff is distinctly bedded, as is well shown in the downward continuation of the Sunshine stope below level 3 , but a few feet above the base it is a typical unbedded nuée ardente deposit with numerous inclusions of andesite. It is immediately underlain by the clay at the unconformity. Many of the ore shoots are capped with this clay, and some of them, con. taining especially high-grade ore just benesth it, may be said to bear out the dam hypothesis, which was early applied to quicksilver ores by Udden ${ }^{18}$ and has been vigorously championed in recent years by Schuette ${ }^{19}$ and others.

\section{RESER VES}

Between 1942 and 1944, principally because of a labor shortage, little exploration and development work was carried on. As a result, the reserves of blocked-out ore in the Horse Heaven mine dwindled greatly.

The ore shoot in the southeast end of level 1, developed by three sublevels 40,60, and 110 feet below that level, contains an unknown though probably small amount of ore below the 60 -foot sublevel. This ore is not expected to continue downward for more than 20 feet. The 110-foot sublevel, where no ore was found, cuts the contact of the intrusive rhyolite and the rhyolite tuff but did not enter the characteristic clay at the unconformity above the Clarno rocks that is present on the 40- and 60-foot sublevels. The contact between intrusive rhyolite and rhyolite tuff on the 110-foot level dips to the northwest, so that the tuffs, which acted as a hanging-wall cap for the ore body on the higher levels, are locally on the footwall side of the contact. Plate 35 indicates that the structure above the 40 -foot sublevel, where the contact is faulted and offset, is probably repeated below the 110foot sublevel. Exploration should therefore continue at deeper levels.

\footnotetext{
18 Udden, J. A., The anticlinal theory as applied to some quicksilver deposits: Texas Úniv. Bull. 1822, 1918.

${ }^{19}$ Schuette, C. N., The geology of quicksilver ore deposits: California Jour. Mines and Geology, vol. 33, pp: 38-50, 1937 .
} 
Easily minable ore remains alongside some of the large stopes opened in the brecciated portions of the rhyolite plug between levels 3 and 7. Most of the high-grade ore in this ground has already been mined, but small ore shoots along the walls of some of the stopes contain an unknown but probably considerable tonnage of low-grade ore. In 1944, much ore of this character was.mined between levels 4 and 7 . The enlargement of the stopes, combined with the weakening of supporting pillars by removal of the ore in them, resulted in the caving to the surface of the stope 1 area. As a result, much of the central part of the mine is now inaccessible.

Some ore still remains in the block between the sublevel 4 and level 6 (east) stopes, but this block probably was almost mined out by the end of 1944. Considerable ore remains, also, in a block surrounding winze 3 between levels 4 and 6 , but this ore can be taken out only by way of the Manway shaft. In addition, a quantity of very highgrade ore has been left within the plug as pillars in stopes and adjacent to winzes.

\section{FURTHER POSSIBILITIES}

Although relatively little ore was in sight at the Horse Heaven mine in November 1944, the outlook with regard to reserves of probable ore was in general promising.

No ore was discovered on level 10 , so that the bottom of the ore body in the rhyolite protrusion has probably been reached. Geological complications between levels 9 and 10 may have had an important bearing on ore deposition here. As the base of the andesite was penetrated in the Manway shaft at an altitude of 2,988 feet, the andesite ceases to form the northeast wall of the rhyolite protrusion a few feet below level 9 , its place being taken by the tuffaceous sediments of the Clarno formation, stratigraphically below the andesite (pl. 31). This change of wall rock may have affected the deposition of the ore, but its influence would necessarily have been small, since most of the ore lies on the southwest side of the protrusion directly beneath the clay above the Clarno formation. Unlike the andesite, this clay will probably persist to great depths. As shown in plate 31, however, the clay is directly above the rhyolite protrusion a few feet below level 9 , instead of in the southwest wall. This fact, coupled with the change from andesite to tuff on the northeast wall. may explain the absence of any ore shoots below level 9 .

Several ore shoots in the andesite directly beneath the clay at the unconformity have been mined between levels 6 and 9 . These ore shoots lie above the rhyolite protrusion and were controlled principally by the clay; hydrothermal solutions rising from the rhyolite protrusion and diverted by the clay deposited the cinnabar beneath 
it. Further exploration along the contact between the andesite and the clay is warranted, particularly to the west and downward.

It seems likely that only a few of the numerous ore shoots in the autobrecciated zones of the main plug will continue downward below level 7. A diamond-drilling program was begun by the company. late in 1942 to determine whether the ore shoots extend below the main stopes. The results were not encouraging, but there may be some small shoots of milling ore at this depth even though the main part of the plug is not so thoroughly mineralized here as it was at higher levels. This apparent dying out of the mineralization with depth takes place at about the level where the plug begins to flare outward in all directions. Also, the flaring southern part of the plug is much less thoroughly autobrecciated than the northern and eastern edges of the plug. On level 6 milling ore has been found only in the northeastern part of the plug. The clay-capped southwestern contact, which was the most favored place for ore shoots on the higher levels, has been penetrated on this level by a crosscut and several drill holes. Although the rhyolite beneath it is impregnated with marcasite and usually shows some cinnabar, no bodies of milling ore have been found on the contact below level 5 except the rich ore shoots that follow down the axis of the protrusion extending from the plug to the west. At this contact, however, mineralization is notably spotty on all levels, and the relative paucity of ore shoots on levels 6 and 7 as compared with levels 3,4 , and 5 does not necessarily mean that the bottom of the ore-bearing zone of the main plug has been reached.

New ore shoots may be discovered in and adjacent to the two rhyolite dikes. The Sunshine stope extends along the northwest dike, and spotty showings of cinnabar were found on the walls of this dike on levels 7 and 8 in the vicinity of winze $\mathrm{C}-6$. Little prospecting has been done between these localities, although the rhyolite dike was exposed for a part of its length by the drift at the northwest end of level 4. This drift was caved and inaccessible in 1942, but drill cores taken at a station near its end show that the rhyolite of the dike, as well as the rhyolite flow that lies to the south, have been thoroughly altered to a waxy clay. The rhyolite flow and the pumiceous rhyolite tuff exposed in the uncaved portion of the drift to the south are similarly altered. The clay contains persistent but thin veinlets of cinnabar at several places both in the drift and in the drill cores, but as the veinlets are widely scattered and the heavy ground hard to move, little stoping was done in this vicinity. It is quite possible that the clay diminishes rapidly with depth and that heavier concentrations of cinnabar may be found in the more permeable portions of the dike and its wall rock below the clay zone.

Since ore was found above the northwest dike, new shoots will probably be discovered along the southeast dike. The large ore shoot 
of the Little Flower stope and some small ore shoots mined near the east end of level 1 are in or near this dike. Good ore was found in a winze in the Lost Mine adit above level 1 near the head of the Little Flower stope. The ore shoot as seen in this exposure is small, but the ore assayed from 2.8 to 21.6 pounds of mercury per ton. The shoot is very likely an upward continuation of the Little Flower. From these discoveries it appears that minable ore occurs here and there along the dike almost throughout its exposed length, a total distance of approximately 550 feet. In the Little Flower stope the ore shoot was continuous for a horizontal distance of about 200 feet, although its vertical range was not great. Additional prospecting along the dike is warranted, for almost nothing is known about the shape and extent of the dike below level 1. In September 1942 a little exploration work was done by extending the drift at the southeast end of level 4, and five holes were drilled. However, this drift had only reached the $5200 \mathrm{E}$. coordinate, so that below level 1 the dike is still almost unprospected. The drift on level 4 passed from highly altered intrusive rhyolite, containing much clay and marcasite, into the andesite flow, the tuffs of the Clarno formation, and a thin dike of rhyolite. A small protrusion on the rhyolite plug thus appears to pass beneath the andesite flow (pl. 26):

As already stated, the southeast dike may enlarge into a subsidiary plug at the southeast end of level 1; not enough exploration work has been done to delimit its contacts. Definite evidence that the dike enlarges outward on the south side or else flattens in dip is furnished by drill hole UG-60, which passed through the contact of the rhyolite with the clays at the unconformity about 65 feet southwest of the intersection of this contact with the surface, indicating that here the contact dips about $45^{\circ} \mathrm{SW}$. The small ore body mined at the southeast end of level 1 extends along this contact and is in brecciated rhyolite beneath the clay at the unconformity (pl. 35). Along this part of the intrusive rhyolite "dike," therefore, the structural conditions are the same as those along the southwest side of the main plug-at both localities autobrecciated rhyolite is capped by the clay at the unconformity along a southwest-pitching contact.

The large mass of hydrothermally altered rock surrounding the West Rock plug also invites prospecting. The plug itself is intensely autobrecciated, and in some of the zones of breccia the rhyolite contains traces of cinnabar and is altered to a black clay like that found in similar zones in the Horse Heaven plug. Other parts of the plug, however, are unaltered and therefore unfavorable to prospecting. The wall rocks on the southwest side of the plug are intensely altered for a distance of several hundred feet along the contact (pl. 22).

To summarize: The proved ore reserves at the Horse Heaven mine had dwindled to a very small tonnage by the end of 1944 . The future 
of the mine depends on the discovery of new ore and on whether the ore shoots in the southeast end of level 1 continue downward. New ore shoots will probably be discovered in the main rhyolite plug below level 7, but it is unlikely that they will be either as closely spaced or as large as those found above this level. There is a good chance of finding new ore shoots along the two dikes that extend from the plug. When all these possibilities-most of them admittedly speculativeare considered, it appears that the mine may produce considerable quicksilver in the future. Production, however, is likely to come from smaller and much more widely spaced ore shoots than those mined heretofore. To find and exploit these ore shoots economically will require careful application of the geologic principles controlling ore deposition in the area.

\section{AXE HANDLE MINE}

The Axe Handle quicksilver mine is 32 miles east-northeast of Madras, Oreg., and 4 miles east of Ashwood, in sec. 35, T. 9 S., R. 17 E. (fig. 7). It is reached by a graded but otherwise unimproved road that also serves the Horse Heaven mine, 12 miles farther east. The mine workings are on the slopes of Axe Handle Butte, a prominent topographic feature that rises 400 feet above the surrounding area and forms a distinctive landmark.

The mine area was prospected as early as 1865 , but until the discovery of the Horse Heaven deposits in 1933 quicksilver was overlooked in the search for gold and silver. Sufficient quantities of both gold and silver were found to warrant exploration in several places near Axe Handle Butte and the development of the Oregon King mine, 4 miles to the northwest, which has been worked intermittently for gold, silver, copper, lead, and zinc. Considerable exploration work was done, also, at the old Red Jacket mine in secs. 25, 26, 34, and 35, T. 9 S., R. 17 E., immediately north and northwest of the Axe Handle mine. In 1900 and 1901 about 1,000 feet of adits and a number of shallow shafts were dug along the silicified shear zone north of the Axe Handle mine; cinnabar was uncovered, yet the quicksilver possibilities of the area still remained unnoticed.

In 1935 commercial quantities of cinnabar were found by L. C. Swanson and Charles Swanson at the present site of shaft 1 and later at other scattered localities around Axe Handle Butte. In 1936 the Swansons and Charles Lowther drove adit 1 to crosscut the ore; they installed a small Champion-type rotary retort and produced a few flasks of quicksilver. In 1938 Horse Heaven Mines, Inc., leased the property, developed the ore body through shaft 1 and levels 45 and 75 , and trucked the mined ore to the Horse Heaven furnace, but in 1939, owing to the low price of quicksilver, the lease was given up. In 1940 the mineral rights were purchased by Guy Wharton, L. C. Swanson, 
and Danny Swanson, who installed a 25-ton Lacey rotary furnace. In 1942 the old Red Jacket claim was added to the Axe Handle property. In 1943 Guy Wharton purchased the Swansons' interests and operated the mine for a few months but had to close down for lack of labor. The workings were all caved or flooded in December 1943.

\section{GEOLOGY AND ORE DEPOSITS}

\section{STRUCTURE}

Axe Handle Butte consists of a central plug of uniformly columnar andesite intruded through the flows of porphyritic andesite that constitute the country rock of the area (pl. 36). The intrusive andesite is a black, fine-grained, glassy augite andesite similar to the feldspathic augite andesites of the Horse Heaven district. The extrusive porphyritic andesite is of variable texture and is altered in varying degrees. It ranges in color from dark green to black and is speckled with bright red-brown hematite aggregates replacing ferromagnesian minerals.

The plug pitches westward at a moderate to low angle (pl. 36) and shows an east-west elongation parallel to the principal direction of shearing in the area. A small offshoot of the same black, fine-grained columnar andesite crops out about 500 feet northwest of shaft 1 , pitches east at an angle of $45^{\circ}$, and presumably joins the west-pitching plug several hundred feet beneath the surface.

The contact between the columnar andesite plug and the surrounding porphyritic andesite varies greatly in dip. Northwest of the New Strike prospect it dips about $50^{\circ} \mathrm{W}$. to SW., but it flattens to $30^{\circ}$ $\mathrm{SW}$. at inclined shaft $\mathrm{P} 15 \mathrm{~B}$, west of which, on a line passing through shaft 2 , it steepens progressively until it swings through the vertical; at the northwest corner of the plug, nearest shaft 1, it has a reverse dip of $20 \% \mathrm{~W}$. The contact also steepens southwestward from a point above the New Strike, becoming vertical on the southwest corner of the plug. In the Dead End shaft it dips $70^{\circ} \mathrm{SE}$., inward toward the plug, then swings through the vertical and flattens to the $20^{\circ} \mathrm{W}$. reverse dip on the northwest corner of the butte.

\section{HYDROTHERMAL ALTERATION AND MINERALIZATION}

The fine-grained intrusive andesite of the Axe Handle Butte plug is unaltered except close to the contact, but most of the extrusive porphyritic andesite in the area is thoroughly altered. Hydrothermal alteration and mineralization are conspicuous in three localities: (1) the contact zone, including the Dead End shaft and shafts P15B and 2 ; (2) the shaft 1 area; and (3) the Red Jacket silicified zone.

Contact zone.-The intrusive andesite close to the contact has largely been. altered to clay minerals. It contains a little secondary quartz in seams and isolated grains. The extrusive porphyritic andesite has 
locally been silicified, then altered to a gray-buff, claylike material in which the original rock textures are perfectly preserved. Cinnabar is locally abundant in this material, but minerals associated with it elsewhere in the area are absent.

Shaft P15B and the shaft 2 workings are entirely in the highly altered porphyritic andesite. Inclined shaft $\mathrm{P} 15 \mathrm{~B}$ pitches $28^{\circ} \mathrm{SW}$. for about 80 feet directly beneath the contact; it supplied most of the ore retorted during 1943. Shaft 2 (pl. 36), farther from the contact, followed ore along a shear zone parallel to the contact for the first 15 feet, then passed beneath the ore. Drifts on levels 36 and 53 from shaft 2 (pl. 37) developed little ore but were driven haphazardly without regard to the contact. The shaft was caved 8 feet below level 36 .when first examined and was completely caved in December 1943.

The Dead End shaft (pl. 36) was sunk on the contact to a depth of about 40 feet. In 1943 it was partly filled with water. A short drift from the bottom is said to have found good ore beneath the contact, which there flattened considerably, Seams and stringers of cinnabar occur: in both the fine-grained and the porphyritic andesite.

Shaft 1 area.-The mineralized area at shaft 1 (pls. 36, 37) is entirely. in white or gray to buff clay formed by complete alteration of the porphyritic andesite flows. The alteration here, in contrast to that in the contact zone, is localized along a mineralized shear zone. Adit 1, which is accessible from the original incline 1, passes through andesite progressively altered toward the shear zone, which indicates that the alteration is definitely localized along the zone of shearing:

The shear zone along which the ore body extends trends N. $85^{\circ} \mathrm{W}$. and dips $62^{\circ}$ to $18^{\circ} \mathrm{S}$., its average dip being $45^{\circ} \mathrm{S}$. Dips in the east drift of level 45 are generally lower than those in the west drift, and the strike of the mineralized zone is different on the surface from that on level 45 . Local swellings in the ore body occur where the shear zone flattens; they are best shown in north crosscut 1 (pl. 37) and at the west end of level 75 .

The mineralized shear zone is cut by normal faults that strike about N. $30^{\circ} \mathrm{E}$. and dip $50^{\circ}$ to $70^{\circ} \mathrm{SE}$. Four such faults are exposed in the workings. The greatest offset may be seen in the east end of level 45 , where a cross fault displaces the ore body about 40 feet to the northeast. (pl. 37). Elsewhere the amount of movement is undeterminable or equivalent to no more than a few feet.

The clay is locally impregnated with cinnabar, which also occurs in seams and veinlets. Marcasite and gypsum are abundant throughout the mine, especially in the west drift of level 75, where considerable native sulfur also occurs in the ore. 
Red Jacket silicified zone.-A number of adits and shallow shafts known as the Red Jacket workings (pl. 36) penetrate the altered porphyritic andesite on the north and west sides of the Axe Handle area. Most of the openings were made in 1900 and 1901 and are now caved or partly filled with water. They were located along a silicified shear zone that attracted the early prospectors. Although gold and silver were found, exploration failed to develop a body of milling ore. In more recent years the owners of the Axe Handle mine explored part of this zone, discovered several small pockets of darkgray, antimony-bearing cinnabar in the Hi-Grade shaft, and produced a few flasks of quicksilver.

The Survey party examined all the workings that were accessible. The silicified zone was found to be characterized by an east-west zone of shearing parallel to the elongation of the plug and to the mineralized shear zone seen in shaft 1 . The shear planes generally dip to the north at high angles and are frequently mineralized with pyrite, marcasite, stibnite, jarosite, and traces of ordinary cinnabar; locally they contain abundant masses of a dark-gray, antimony-bearing cinnabar. Gold and silver are said to have been found.

\section{POSSIBILITIES OF AREA}

Cinnabar reputedly can be panned throughout the Axe Handle area. This widespread distribution is partly the result of slope wash and soil creep, but test pits on the lower slopes of Axe Handle Butte and on the south side of Randolph Gulch show traces of cinnabar at many localities in the altered porphyritic andesite.

The most favorable part of the area lies along the edge of the plug ibetween the New Strike prospect and shaft 2. This locality is marked by a zone of hydrothermally altered rock, and ore shoots have been found below the surface at either end of it. Surface rubble and slide rock are seldom more than a foot or two thick, so that trenching and test pitting are simple. The success of shaft P15B, also, indicates :that similar ore shoots may be expected between it and shaft 2 .

In the shaft 1 ore body some ore remains as shaft pillars and as unmined areas between levels. In the west end of level 75 and between the surface and the east drift of level 45, possibilities for ore are good. No adits to the Red Jacket silicified zone were accessible, but surface indications are not promising. Any ore bodies within the zone will probably be pockety and similar to the ore in the Hi-Grade shaft.

To summarize: Mineralization at the Axe Handle mine is closely related to the andesite intrusion. Cinnabar was deposited along eastwest shears formed by stresses accompanying the intrusion and was concentrated peripherally beneath the overhanging contact of the intrusive andesite. There is no assurance that the mineralization continues more than a few feet below the present workings, but with planned development it is likely that the mine will produce more ore. 


\section{HORSE CREEK PROSPECT}

The Horse Creek prospect, owned by Bert Roark and Glenn Stephenson, is near the headwaters of Cherry Creek in the west half of sec. 9, T. 11 S., R. 19 E. It is about half a mile southwest of the junction of Horse and Cherry Creeks and 10 miles south of the Gonser Road. The main workings are on the west side of a steep hill that separates Horse Creek from Cherry Creek; they overlook Horse Creek: and lie at an elevation of 3,500 feet. The prospect is accessible by a good trail, and in the summer it can be reached, though with difficulty, by automobile.

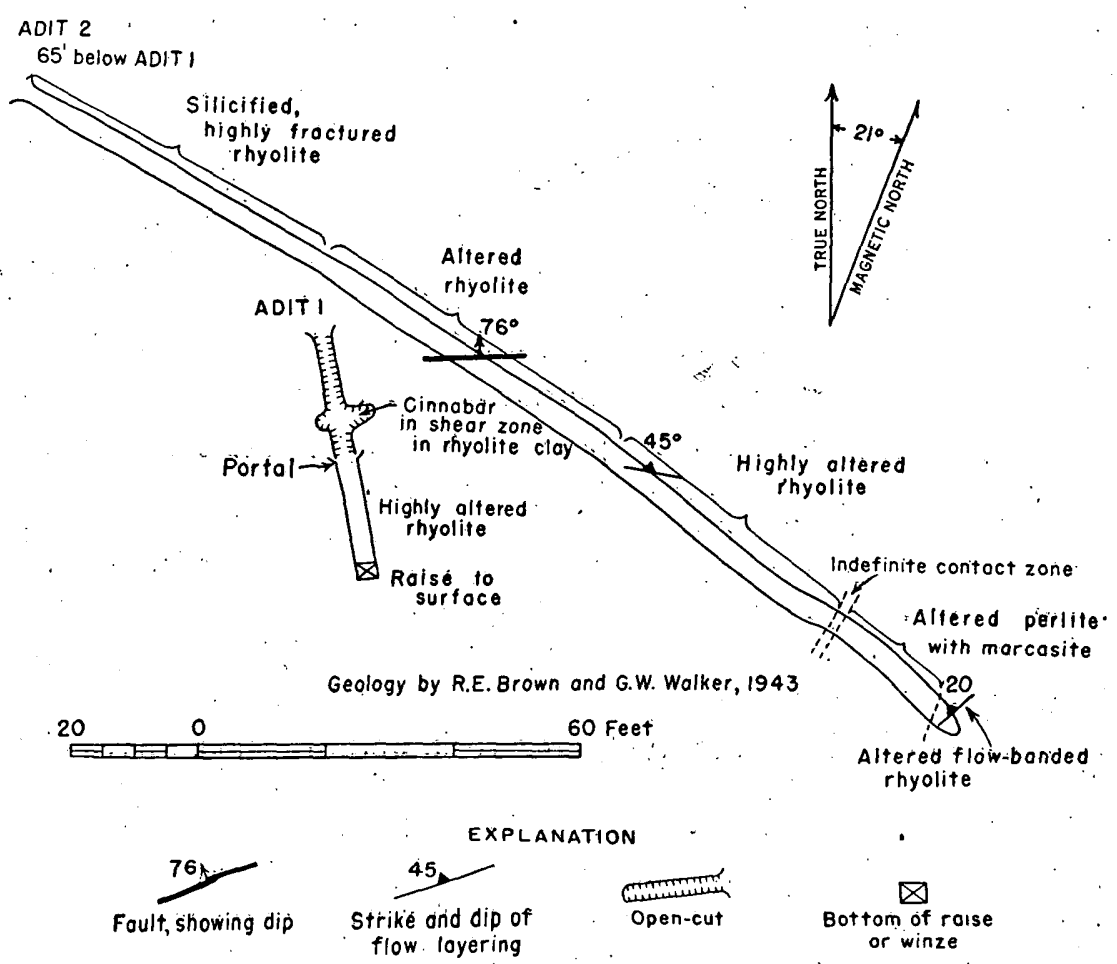

Figorn 8.-Plan of Horse Creek prospect; Jefferson Ciounty, Oreg.

The hill has been carved from a biotite rhyolite plug. Two adits: have been driven in it. On the opposite side of Horse Creek are a: number of test pits, trenches; and short adits in highly altered andesite (fig. 8). In the upper adit abundant cinnabar, mostly in the form of "paint," occurs in highly altered and weathered rhyolite largely converted to clay. The association of cinnabar with the biotite rhyolite: plug is similar to that at the Horse Heaven mine. The lower adit, driven to cut the ore shoot at greater depth, penetrates the hill for 176 : feet without showing a trace of cinnabar. It traverses first a zone of silicified rhyolite near the portal, then a zone of increasingly altered rhyolite. Finally it enters a body of black clay-probably derived 
from perlite-containing abundant gypsum, epsomite, and finely divided marcasite, which gives it a dark color.

The hill is capped by a flow of scoriaceous augite andesite similar to that in the southern part of the Horse Heaven district. Fragments. of perlite are abundant on the hillside. The numerous shallow pits on the north side of Horse Creek contain no visible cinnabar, although. they are dug in hydrothermally altered andesite. None of the pits, however, definitely penetrates below the zone of weathering.

\section{ASHWOOD PROSPECT}

The Ashwood prospect is in sec. 6, T. 10 S., R. 17 E., from a quarter to half a mile east of Ashwood. The prospect lies along the contact. zone between the intrusive biotite rhyolite plug of Ash Butte and the surrounding porphyritic andesites. The main workings are on the east and south sides of the butte, a very steep and prominent feature and one of several similar buttes in the district; prospect pits are scattered over an area of more than a square mile. Several operators have worked the prospect intermittently in the past. During 1938. and 1939 it was mined by Guy Wharton and the Swansons, who. trucked about 20 tons of ore to their retort at the Axe Handle mine. In 1939 the prospect was abandoned; and it has not been worked since.

Some of the workings are caved, among them several prospect adits. on the east side of the plug. The dumps indicate that these adits were several hundred feet long. In the southern part of the contact zone there are several short adits, none over 30 feet long, together with. many shallow pits and an inclined shaft 30 feet deep. Few of the workings penetrate below the zone of weathering. No cinnabar was. seen in them, although abundant marcasite was noted in seams and. fractures in the porphyritic andesite in the inclined shaft.

The ore trucked to the Axe Handle retort came from several adits: about 300 feet east of the contact. The lowest adit extends southward. into the hill for 200 feet; it leads away from the contact and passes: through progressively less altered porphyritic andesite. The tunnel crosses several shear planes, trending west and dipping to the south, that contain cinnabar associated with calcite, silica, marcasite, and gypsum. The uppermost adit, which is the one most recently worked, produced most of the ore but is mined out. It does not penetrate. below the zone of weathering.

Further prospecting along the contact zone may determine whether the cinnabar is concentrated primarily in the biotite rhyolite plug, - as it is at the Horse Heaven mine, or in the porphyritic andesite surrounding the plug, as at the Axe Handle mine.

The occurrence, at Ash Butte, of cinnabar closely associated with a biotite rhyolite plug indicates that Greater Butte and other similar rhyolite plugs in the area should be prospected. 


\section{LOWREY PROSPECT}

The Garnet No. 1 Lode claim staked in 1941 by Elvin D. Lowrey is on the crest of a ridge about a quarter of a mile north of Muddy Butte in sec. 3, T. 10 S., R. 18 E. The vertical discovery shaft, which is 54 feet deep, passes through a thin zone of hydrothermally altered lapilli tuff into altered andesite. Cinnabar and calcite occur in a thin vertical stringer in highly altered andesite. The area pans poorly except close to the shaft. The mineralization is probably related to the intrusive plug of biotite rhyolite composing Muddy Butte, this plug presumably being the source of the solutions that altered the andesite. Where exposed elsewhere in the Muddy Butte area, the andesite is not altered.

\section{CHERRY CREEK PROSPECT}

The Cherry Creek prospect was located in April 1943 by Glenn Stephenson, Bert Roark, and Glenn Frier. It lies on the east side of Cherry Creek, about 3 miles east of the Horse Heaven mine, in the $\mathrm{S} 1 / 2$ sec. 16 and $\mathrm{N} 1 / 2$ sec. $21, \mathrm{~T} .10 \mathrm{~S}$., R. 19 E. The prospect includes two claims. It was not visited, but the exploration work is said to consist of a shallow open-cut and a short adit.

\section{OTHER PROSPECTS}

Many abandoned prospect pits, adits, and shafts in the area shown on plate 21 were visited, but only a few showed cinnabar in place. Because of the abundance of landslides and thick mantles of creeping soil, cinnabar.commonly appears as float in debris far from the nearest outcrop of mineralized rock. Prospectors have found this wandering float at many localities and have dug pits or other workings at the site of the discovery only to find that the creeping mantle was underlain by barren rock. Several such pits dot the surface down slope from the saddle in which the Horse Heaven mine is located. The cinnabar found in them was carried by soil creep from ledges already located; so that it now has no economic significance.

There is, however, a similar cluster of prospect holes located in the drainage area of the West Fork Horse Heaven Creek just east of Burnt Butte. These pits are so situated that they could not receive creeping soil from any mercury-bearing bedrock that has yet been found.

Several abandoned prospect pits, many of them now caved or flooded, may be seen from the road between Ashwood and the Horse Heaven district. Many of these were dug in 1900 and 1901 in the search for gold and silver, but as this area also contains many plugs of rhyolite, it should be a favorable one in which to prospect for cinnabar. 


\section{N DEX}

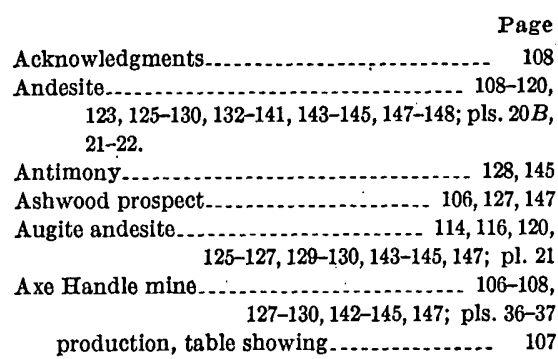

Basalt. 108,115

Basaltic andesite. 118-121, 126; pl. 21

Breccia, brecciation 136-137, 139-141; pl. 22

Burnt Butte volcanic center. 120-122; pl. 22

Cherry Creek prospect. .................... 106, 148 Cinnabar... 107, 109, 127-130, 134, 139-140, 142, 144-148 discovery of . . ......................... 109

Clarno formation.109-118, 126, 130, 133-139; pls.20 B, 21

Clay and clayey soils. . . .................... 109-110 $112-115,117-119,124-130,132-133,135-141,144$ 146-147; pl. 21.

at unconformity

118-119, $126-127,130,133,135-141 ;$ pl. 21

Clay minerals. ........................... 128-129, 143

Climate...................................... 107

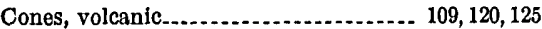

Dikes.... 112, 115, 121, 126, 134-135, 137, 140-141; pl.22

Equisetum, fossil stems of.................... 113

Exploration, history of . ................ 107, 142-143 possibilities for future....... 129-130, 138-142, 145

Field work Fossils Future possibilities............. 129-130, 138-142, 145

Geology 108-127; pls. 20B, 21-22 Gold and silver................... 107, 128, 142, 145, 148 Ground water

Gypsum $128-129,144,147$

Hinkle Butte volcanic center 118-121,

Horse Creek prospect

124-125, 137; pls. 21-22 106, 127, 146-147 "Horse Heaven fault" ......................... 111, 133

Horse Heaven mine....................... 106-108, $110-111,114,121,124,127-128,130-142$, 146-148; pls. 20 A, 23-35.

production, table showing ................ 107

Eydrothermal alteration... 110, 116, 118, 121, 124-130, $132,134,139,141,143-145,147$; pl. 22

Investigation, present

108

Jarosite $128-129,145$

Landslides

Lignite. $110,119,126-127,129-130,148$ $118,133,135-136$
Page

Literature ...................................... 110-111

Location of area.......................... 106-107

Lowrey prospect................... 106, 127, 148; pl. 22

Marcasite

128-129,

$132,134,136,140-141,144-145,147$

Mercury, native............................ 128

Metacinnabar.............................. 128-129

Mineralogy ................................. 128-129

Mines and prospects.... 106, 130-148; pls. 20 A, 23-37

Mining, history of................. 107, 142-143, 147

Muddy Butte volcanic center............. 120; pl. 22

Mudflow deposits................... 113-115, 117, 137

Necks, volcanic.............. 109-110, 112, 116-117, 126

Nuée ardente deposits........ 111, 122-123, 138; pl. 21

Ore, favorable localities for ..... 129-130, 138-142, 145 mineralogy of ......................... 128-128 structural control of deposits.... 127-128, 132-145

Perlite..................................... 124-125, 140

Petrography. See Stratigraphy and petrog. raphy.

Plugs and domes, volcanic..... 109, 115-117, 120-125, 127-130, 132-143, 145-148; pls. $20 \mathrm{~B}, 21-22$ Post-Clarno rocks...................... 118-127; pl. 21 Pre-Tertiary rocks......................... 111; pl. 21

Production........................... 107, 142, 147

Prospectors, suggestions for..... 129-130, 138-142, 145 Pumice lapilli tuff . ..................... 111, 113-114, 120-123, 126, 132-133, 135-138; pl. 21

"Quartz basalt"................................. 114-115

Quartzite................................ 109,111, 119

Red Jacket workings................ 128, 143, 145; pl. 36 Reserves................................. 138-142, 145 Rhyolite and associated pyroclastics....... 100-114, 118-130, 132-142, 146-148; pls. 21-22

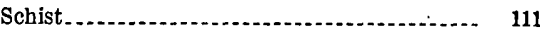

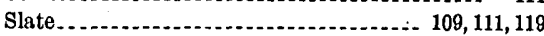

Soil. See Clay and clayey soils.

Soil creep..................... 110, 126-127, 129-130, 148

Solfataric alteration................. 109, 116-117, 124

Springs...................................... 119, 126

Stratigraphy and petrography.............. 111-127;

126-127; pl. 21

Topography

Tuff and tuffaceous sediments............. 109-114, 117-123, 126-128, 132-140, 148; pl. 21

Tuff-breccia . . ................... 121, 123, 125; pl. 21

Unconformity above Clarno formation, clay at. 118$119,126-127,130,133,135-141$; pl. 21

Water tables, perched........................ 118

West Rock volcanic center................. 120-122, $124-125,132,135,137,141$; pl. 22 